\title{
LIMITES NORMATIVOS DA RESPONSABILIDADE DO ESTADO POR DANO TRIBUTÁRIO NO DIREITO BRASILEIRO VIGENTE
}

\author{
STATE LIABILITY ON TAX DAMAGE - LEGAL LIMITS IN CURRENT BRAZILIAN LAW
}

\author{
Andreia Cristina Scapin ${ }^{*}$
}

\begin{abstract}
Resumo:
O propósito deste artigo é investigar os limites normativos da responsabilidade do Estado no âmbito das relações tributárias, emergentes da obrigação do contribuinte (ou responsável) de pagar tributos, a partir da interpretação do conjunto de enunciados prescritivos do Direito brasileiro vigente que versam sobre o exercício da função fiscal e sobre o dever jurídico de reparar danos dispostos na CF/88, no CTN e no CC/02, confrontando-os com a doutrina e a jurisprudência existentes sobre o tema. Serão examinadas algumas decisões proferidas pelo Supremo Tribunal Federal (STF), pelo Superior Tribunal de Justiça (STJ) e por Tribunais Regionais brasileiros para verificar como o instituto tem sido compreendido por esses tribunais.

Palavras-chave: Norma jurídica. Sanção. Responsabilidade do Estado. Dano. Função fiscal.
\end{abstract}

\begin{abstract}
:
This paper aims to verify the legal limits of the State liability under Tax Law, founded on the duty to pay taxes, from the interpretation of some Brazilian Law mandatory statements related to the tax administrative activity and also the duty to pay damages stated on the Federal Constitution, on the Tax Law Code and on the Civil Code. Comparisons among these acts, legal scholarship and case law related to this subject were made. Some Brazilian Superior Courts (STF and STJ) and Court judgments delivered from 1988, when the current Brazilian Constitution was enacted, will be analysed. The idea is to investigate how this issue has been interpreted by the aforementioned Courts.
\end{abstract}

Keywords: Rule of law. Sanction. State liability. Damage. Tax function.

1. Introdução: corte metodológico para a delimitação do objeto de estudo

O tema da responsabilidade do Estado por dano tributário desperta interesse não apenas porque foi pouco explorado pela doutrina e jurisprudência brasileiras num momento em que diversos países já o analisaram, dada a significativa correlação entre a imposição de tributos e os direitos fundamentais, mas sobretudo por propor um intrigante

Doutora em Direito Tributário pela USP. Doutorado Sanduíche desenvolvido na Università degli Studi La Sapienza di Roma pelo Programa CAPES em 2015. Mestre em Direito Penal pela USP. Especialista em Direito Tributário pela USP. E-mail: andreiascapin@vslaw.com.br. 
diálogo entre dois ramos do Direito que, à primeira vista, parecem tão opostos, porém, na verdade, estão mais próximos do que se pode imaginar: Direito Civil e Direito Tributário.

Apesar da responsabilidade do Estado regular-se por princípios compatíveis com as peculiaridades da posição jurídica estatal e de estar prescrita no art. $37, \S 6^{\circ}$ da CF, o tema se insere no âmbito da responsabilidade civil, especificamente da responsabilidade extracontratual ou aquiliana regulada nos arts. 186, 187 e 927 do CC, portanto, perpassa pelo Direito Civil.

Essa espécie de responsabilidade aplica-se à Administração Tributária, pois é o setor especializado da Administração Pública em exercer a função fiscal - que corresponde às atividades de fiscalização, constituição, inscrição e cobrança do crédito tributário -, conforme disposto no art. 37, incisos XVIII e XXII da CF. Logo, além do dever de praticar seus atos em obediência aos princípios de legalidade, impessoalidade, moralidade, publicidade e eficiência, estabelecidos no caput de tal artigo, por meio dos quais o legislador constituinte deixou implícita sua submissão ao dever de não causar danos a outrem (neminem laedere), está obrigada a ressarcir eventuais prejuízos resultantes da conduta dos agentes públicos a ela vinculados em razão da prescrição do $\S 6^{\circ}$ do mesmo dispositivo.

De fato, este estudo confirma a premissa de que o Direito é um sistema e que a construção da norma aplicável resulta do entrelaçamento dos enunciados prescritivos existentes nos setores Constitucional, Tributário, Administrativo e Civil, ou seja, não decorre unicamente da inteligência do $\S 6^{\circ}$ do art. 37 da CF. Isso porque, para compreendê-lo profundamente, requer-se a análise de suportes físicos que disciplinam o conceito de dano, conduta, culpa e nexo de causalidade, estabelecidos no Código Civil; de entidade, órgão e agente público, disciplinados na legislação administrativa para regular a atuação da Administração Pública, isto é, da Administração Tributária; e, das limitações ao poder de tributar, no que se insere o exercício da função fiscal, postos na CF e no CTN.

O aprofundamento científico da matéria tornou-se imperioso em razão da crescente insatisfação do cidadão com a ineficiência da Administração Tributária nos últimos anos no Brasil, que ensejou um considerável aumento de ações judiciais propostas pelos contribuintes que se sentiram lesados por condutas de agentes públicos que revelaram descuido na prática de atos de cobrança de tributos ou desproporcionalidade na adoção das medidas voltadas à perseguição do crédito tributário.

Tal cenário é relativamente recente, pois, por longo tempo, a figura do tributo associou-se à típica manifestação da soberania estatal, que incluía os atos tributários dentre aqueles que praticamente não ensejavam a responsabilização do Estado. Além disso, havia certa resistência do contribuinte em confrontar a Administração Tributária, não só pelas dificuldades impostas pelo próprio legislador, mas principalmente pela preocupação com futuras retaliações. 
A essência da problemática é o fato de que o traço marcante das relações tributárias é a bipolaridade, já que há dois valores em constante tensão: a autoridade do Poder Público e a liberdade individual do contribuinte. Por um lado, a imposição de tributos consente a aquisição de recursos financeiros destinados à manutenção e à existência do aparelho estatal, ao desenvolvimento de atividades e serviços públicos; e, em geral, ao cumprimento dos deveres para os quais o Estado tem sido chamado propiciando maior distribuição de riqueza entre os indivíduos que compõem a sociedade. Por outro lado, permite que o direito fundamental à propriedade e, consequentemente, à liberdade do cidadão sejam atingidos com a absorção compulsória de parcela do seu patrimônio que se destina ao custeio de despesas públicas como uma declinação típica do dever de solidariedade política, econômica e social que compete a cada indivíduo que compõe a comunidade nacional.

Desse modo, a ação estatal toca diretamente os direitos fundamentais do contribuinte, não somente como consequência da eleição dos fatos que o legislador constituinte apreende nas regra-matrizes de incidência tributária, mas também pela forma como o Estado exerce a atividade tributante, que pode causar danos de extrema gravidade e até irreversíveis ao contribuinte (ou responsável).

Sublinhe-se que os atos destinados a cobrar tributos praticados pelos agentes públicos vinculados à Administração Tributária inserem-se na categoria dos atos administrativos, sendo dotados de fatores de eficácia - como presunção de legitimidade e exigibilidade -, de modo que, por mais absurda que seja a pretensão tributária, o ato se sustenta e produz efeitos até que sobrevenha uma decisão da própria autoridade fiscal que emanou o ato, ou de hierarquia superior, desconstituindo-o.

Tais atos, que traduzem a função fiscal, constituem normas individuais e concretas, correspondendo aos principais atos que compõem a conduta causadora do dano tributário, quais sejam: i) lançamento tributário de ofício e "autolançamento tributário"; ii) lançamento e imposição de multa; iii) inscrição do débito em dívida ativa; e, iv) ajuizamento da execução fiscal.

Logo, se o contribuinte (ou responsável) não satisfizer a prestação tributária nas condições impostas, a entidade tributante pode aplicar as medidas previstas em lei para o cumprimento forçado da obrigação fiscal, tais como: a inscrição do débito em dívida ativa com a emissão da Certidão de Dívida Ativa (CDA), o ajuizamento da execução fiscal, a penhora de bens e do faturamento da empresa, o cadastro no CADIN, o indeferimento de certidão negativa de débito fiscal ou positiva com efeitos negativos, a restrição à alienação de bens, entre outros.

Consequentemente, o contribuinte se defrontará com situações que inviabilizam a movimentação de seu negócio, podendo até ensejar o encerramento das atividades da empresa, por exemplo: i) negativa de crédito junto às instituições financeiras, 
ii) restrição do suprimento de matéria prima por fornecedores, iii) impossibilidade de participar de procedimentos licitatórios e de concluir vantajoso negócio por constar irregularidades em relação ao pagamento de tributos.

Para evitar tais embaraços, depois de notificado, deverá adotar medidas destinadas à suspensão da exigibilidade do crédito tributário, previstas no art. 151 do CTN, como: impugnar o ato de lançamento ou o auto de infração, administrativamente; ajuizar ação judicial anulatória do débito fiscal acompanhada do depósito do valor do montante integral em juízo; ou, obter a suspensão em juízo liminarmente se comprovado o periculum in mora e ofumus boni iuris.

Em tal contexto, o contribuinte sofrerá danos concretos resultantes das despesas com a contratação de profissionais habilitados, perícias, assistentes técnicos, depósitos judiciais etc. - denominados danos tributários, pois emergem da obrigação de pagar tributo - quando não for surpreendido diretamente com a execução fiscal, até mesmo sem notificação prévia, em que os danos poderão ser ainda maiores dada a possibilidade de penhoras online e sobre o faturamento da empresa, impedindo que os recursos financeiros, que permanecerão indisponíveis, sejam investidos para proporcionar o crescimento do negócio, prejuízo que tende a se agravar com a solução de conflitos tão vagarosa como a que ocorre no Brasil.

Tanto os danos patrimoniais - que se bipartem em dano emergente e lucro cessante - quanto os danos não patrimoniais - ou, o dano moral para o Direito brasileiro resultantes do exercício da função fiscal, deverão ser ressarcidos pelo Estado na presença dos elementos essenciais da responsabilidade analisados a seguir.

Ressalte-se que tais prejuízos somente serão passíveis de ressarcimento se o dano produzido puder ser incluído no âmbito da antijuridicidade, isto é, se for considerado ilícito por revelar a lesão de direitos subjetivos do contribuinte, caracterizando o danoevento, que compõe a noção jurídica de dano. Por isso, se o pagamento do tributo devido não foi feito no prazo e dentro das condições estabelecidas em lei, é lícito à Administração Tributária aplicar as medidas fixadas pelo legislador para perseguir o cumprimento da obrigação utilizando as prerrogativas inerentes ao princípio da supremacia do interesse público sobre o interesse do particular, visto que se trata de uma consequência lógica que o próprio legislador prescreveu em caso de descumprimento de dever jurídico igualmente previsto em lei.

Certamente, o contribuinte (ou responsável) sofrerá prejuízos que, por não se incluírem no sentido jurídico de dano, não comportam ressarcimento pelo Estado, pois, transcorrido in albis o prazo para pagamento do tributo decorrente de uma cobrança legítima, justifica-se a atuação obrigatória do agente público na aplicação de medidas dirigidas à satisfação do crédito tributário, sendo, de consequência, lícito o dano causado por não configurar a lesão de direitos subjetivos do contribuinte (ou responsável). 
Logo, nessa última hipótese, os danos serão reputados lícitos, já que se encontram justificados pela ordem jurídica dada a obrigação de cada membro da sociedade de contribuir para o custeio das despesas públicas e para uma melhor distribuição das riquezas sempre que praticada hipótese de incidência tributária. Não há ilicitude na conduta do agente público que sacrifica legitimamente o patrimônio do contribuinte (ou responsável) em razão do inadimplemento de tributo devido, desde que respeitados os limites da lei. Do contrário, a conduta será ilícita, o que repercutirá também sobre o dano, conforme será analisado a seguir.

2. O reconhecimento da potencialidade lesiva do fenômeno tributário pela $\mathrm{CF} / 88$, a submissão do Estado ao dever geral de não causar dano a outrem e a lesão de direitos subjetivos do contribuinte

Ao introduzir na Constituição Federal de 1988 uma seção para tratar das "Limitações ao Poder de Tributar" (art. 150 a 152 da CF), o legislador demonstrou ter reconhecido o alto potencial destrutivo da imposição tributária e, consequentemente, a necessidade de fixar garantias constitucionais para a proteção do contribuinte, já que, segundo anteriormente mencionado, os fatos tributáveis se atrelam a comportamentos que se conectam às liberdades fundamentais por atingir obrigatoriamente a propriedade e a liberdade, sendo suscetíveis de causar lesão a direitos subjetivos do sujeito passivo da obrigação tributária se exercidos fora dos parâmetros legais estabelecidos por princípios e regras que constituem um limite ao exercício da atividade fiscal, os quais abrangem o conjunto de normas jurídicas - a exemplo da legalidade, anterioridade, irretroatividade, igualdade, capacidade contributiva, não cumulatividade, vedação do tributo com efeitos confiscatórios - que exprimem vedações constitucionais às entidades tributantes no exercício da atividade tributária.

Assim sendo, dentro da lógica de que o Direito é um sistema, além dos princípios dispostos no caput do art. 37 da CF que regulam o modus operandi da Administração Pública - legalidade, impessoalidade, moralidade, publicidade e eficiência -, que foram prescritos justamente para evitar a causação de danos, submetendo inclusive a Administração Tributária, os princípios e regras específicos do setor tributário acima mencionados confirmam a vontade do legislador constituinte de proteger o sujeito passivo da relação tributária dos possíveis danos resultantes especificamente do exercício da função fiscal, razão pela qual demarcou na lei todo o desempenho dessa atividade.

Sob essa perspectiva, entende-se que: a conjugação dos princípios jurídicos tributários que delineiam a prática de atos pela Administração Tributária (art. 150 da CF) com os princípios que regulam o modus operandi da ação administrativa (art. 37, caput, da $\mathrm{CF}$ ) e a previsão da responsabilidade estatal (art. $37, \S 6^{\circ}$ da CF) conduz logicamente 
à conclusão de que, no Direito brasileiro, está presente a norma primária dispositiva: “se é o poder-dever do Estado de tributar o cidadão, então deve ser a proibição de causar-lhe danos"; e, consequentemente, da norma primária sancionadora: "se o Estado causar danos ao cidadão no exercício do poder-dever de tributar, então deve ser a obrigação do Estado de ressarcir os danos causados"; além da norma secundária que determina a ação coativa do Estado-Juiz impondo a execução forçada de bens do infrator, ou seja, do Estado.

O dever do Estado de não causar danos ao cidadão ao exercer as atividades públicas, dentre as quais se inclui a função fiscal, também se confirma em outras normas infraconstitucionais que especificam a cautela do legislador ao regular a atuação da Administração Pública, a exemplo da Lei n. 9.784, de 29 de janeiro de 1999, que prescreve normas de proteção aos direitos do administrado para o melhor cumprimento dos fins administrativos, sobretudo na realização do processo administrativo. Estabelece o art. $2^{\circ}$ da referida Lei: “a Administração Pública obedecerá, dentre outros, aos princípios de legalidade, finalidade, motivação, razoabilidade, proporcionalidade, moralidade, ampla defesa, contraditório, segurança jurídica, interesse público e eficiência”.

Existem, ainda, vários incisos que especificam a conduta que o legislador espera seja adotada pelos órgãos administrativos, tais como o inciso IV que prevê "a atuação segundo padrões éticos de probidade, decoro e boa-fé" e os incisos II e III do art. $4^{\circ}$ que determinam, respectivamente, como dever da Administração Pública: proceder legalmente, com urbanidade e boa-fé e não proceder de modo temerário.

Conclui-se que, ao introduzir esses princípios e regras como uma limitação à imposição tributária por reconhecer seus efeitos nocivos se exercida fora dos parâmetros estipulados, o legislador não somente assegura e defende direitos fundamentais do cidadão e valores como segurança, justiça, igualdade etc., mas torna evidente a existência da obrigação do Poder Público de adotar comportamentos corretos também no setor tributário para não causar danos ao contribuinte (ou responsável), sob pena de se submeter às consequências previstas no art. $37, \S 6^{\circ} \mathrm{da} \mathrm{CF}$, ou seja, ao dever de ressarcir os prejuízos causados.

Frise-se que a atuação da Administração Pública em conformidade com as referidas normas constitui direito subjetivo do administrado, de modo que seu descumprimento caracteriza a conduta e o dano como ilícitos.

Dessa forma, se o contribuinte (ou responsável) sofrer danos em razão do exercício da função fiscal, é possível que se verifique a lesão de duas categorias de direitos subjetivos: i) de regras e princípios tributários de cumprimento obrigatório pela Administração Tributária para a realização de atos voltados à imposição do tributo; e, ii) dos direitos à propriedade e à liberdade.

A lesão desses direitos subjetivos é suficiente para qualificar o dano como ilícito, ensejando o dever de ressarcir do Estado. Noutros termos: a ilicitude do dano 
resulta da violação do direito subjetivo do contribuinte de ser submetido à exigência de tributo com base nos princípios e regras constitucionais tributários; e, da lesão ao direito subjetivo à propriedade e à liberdade, que a violação desses princípios produzem.

A título de exemplo: se o tributo exigido é indevido, ainda que tal fato seja reconhecido apenas após a realização de todos os trâmites judiciais, os atos praticados e as consequências suportadas pelo contribuinte (ou responsável) serão lesivas ao direito fundamental à propriedade e, consequentemente, à liberdade, o que caracteriza a ilicitude do dano, já que, inexistindo o dever jurídico de pagar tributo, não há causa suficiente para fundamentar a aplicação do consequente da norma que determina a adoção de medidas tão agressivas ao patrimônio, rompendo-se o equilíbrio que necessariamente deve existir entre o interesse público de perseguir o adimplemento do crédito tributário e o interesse privado de não ter seus direitos sacrificados além do limite da legitimidade da ação da Administração Pública, sendo cabível, portanto, o ressarcimento do Estado pelo dano causado.

Ademais, se o tributo é indevido, o ato de imposição tributária apresenta vício, tornando-se passível de anulação devido a sua ilegitimidade, que implica sobretudo o descumprimento do princípio da legalidade, razão pela qual não autoriza o sacrifício dos direitos fundamentais do contribuinte (ou responsável). Dito de outro modo: na medida em que o crédito tributário é desconstituído pelo Poder Judiciário dado o reconhecimento de vício que anulou o lançamento tributário, é possível afirmar a inexistência de causa suficiente e relevante que justificasse o peso do alegado devedor suportar os danos resultantes da prática de atos que incidem de modo autoritário na esfera jurídica de seu destinatário, implicando a privação do direito de gozar e utilizar do bem.

A aplicação do consequente da norma primária sancionadora que impõe deveres ao contribuinte (ou responsável) como a sanção pelo descumprimento da obrigação (penalidades pecuniárias ou multas fiscais), além da norma secundária com atos de execução forçada (execução fiscal) - ou seja: a ativação dos instrumentos legais destinados à satisfação do crédito tributário -, só pode ocorrer legitimamente se houver o efetivo descumprimento da norma primária dispositiva, vale dizer: se a dívida em relação à qual o contribuinte figura como inadimplente realmente existir e a cobrança for adequada. Caso contrário, o Estado deve ressarcir o dano causado dado o seu caráter ilícito.

Nessa hipótese, verifica-se o dever jurídico do Estado de ressarcir o dano suportado pelo contribuinte (ou responsável) recompondo sua situação ao status quo ante se for aplicada a sanção estabelecida no consequente da norma primária sancionadora sem a ocorrência de seu pressuposto, vale dizer, sem o descumprimento do dever jurídico prescrito na norma primária dispositiva.

Diante da inexistência do dever de pagar tributo, o dano é ilícito, ou seja, lesivo a direitos subjetivos, já que a ablação do patrimônio e a execução forçada de bens, 
que resulta da relativização de direitos fundamentais imposta pela lei, é permitida somente se houver o dever jurídico de pagar o tributo e o respectivo descumprimento, caso contrário há nítida violação de direitos. Logo, a ausência da dívida caracteriza a ilicitude do dano, ensejando a responsabilidade do Estado.

Nessa lógica, se não há descumprimento do dever jurídico de pagar o tributo ou a multa fiscal pelo contribuinte (ou responsável), o dano decorrente da execução forçada de bens, da contratação de profissionais habilitados, da inscrição no CADIN, do indeferimento de certidões negativas de débitos, revela a lesão de direitos subjetivos como a propriedade, a liberdade e a livre iniciativa, e não a sua legítima limitação.

Sublinhe-se que: o dever de ressarcir um dano requer forçosamente a presença do elemento "ilícito". Conforme Fernando Dias Menezes de Almeida: "para que haja responsabilidade, é necessário que tenha havido conduta ilícita ou resultado ilícito; ou ainda, conduta ilícita que enseja o resultado ilícito". (ALMEIDA, 2008, p. 19).

Logo, a ilicitude do dano independe da ilicitude da conduta, já que decorre do descumprimento da norma primária dispositiva que prescreve o dever de "não causar dano a outrem", cuja consequência, estabelecida na norma primária sancionadora, é a sanção de ressarcimento do dano; ao passo que, a ilicitude da ação causadora do dano, vale dizer, da conduta, resulta do descumprimento de outra norma jurídica qualquer, ou seja, de um dever jurídico preexistente.

Por exemplo: o motorista que supera a velocidade máxima permitida comete um ato ilícito, pois sua conduta é contrária ao Direito, além de culposa. É possível que dessa conduta ilícita de violar a velocidade máxima permitida não resultem danos, ensejando só a imposição de multa, já que não houve violação da norma primária dispositiva "não causar dano a outrem". Todavia, se ao conduzir o veículo em alta velocidade atropelar uma pessoa, a conduta ilícita terá produzido um resultado danoso que também é ilícito, devido à violação da norma geral "não causar dano a outrem", ou seja, da referida norma primária dispositiva.

Em vista disso, a ilicitude da conduta se refere ao descumprimento da norma que impõe o limite máximo de velocidade, diferenciando-se da ilicitude que se verifica no dano, a qual decorre da violação do dever de "não causar dano a outrem", lesando direitos subjetivos ou interesses juridicamente protegidos. Por essa razão afirma Menezes de Almeida que "o dano já traz implícito o significado de resultado ilícito". (ALMEIDA; CARVALHO FILHO, 2014, p. 397).

A lesão de direitos subjetivos ou de interesses juridicamente relevantes que gera a ilicitude do dano se traduz sobretudo na lesão de direitos fundamentais da personalidade e da propriedade e no leque de direitos que resultam da relação normal em um Estado de Direito entre a Administração Pública e os cidadãos, a exemplo do 
direito à legalidade, segurança jurídica, igualdade, imparcialidade, moralidade, boa-fé, à proporcionalidade etc.

No ordenamento jurídico brasileiro, o legislador não especificou nos arts. 186 e 927 do CC quais são os danos que merecem tutela do Direito, visto que utilizou o termo dano de maneira genérica, pois se trata de uma cláusula aberta. No entanto, há na Constituição de 1988 um direcionamento sobre a área de circunscrição do dano passível de ressarcimento mediante a especificação dos direitos e interesses que a ordem jurídica selecionou como tuteláveis e merecedores de proteção, dentre os quais os direitos fundamentais da pessoa humana dispostos no art. $5^{\circ}$ da $\mathrm{CF}$, como a propriedade e a liberdade; e, o direito à livre iniciativa econômica, estabelecido no art. 170 da CF, que constituem objeto da lesão no dano tributário. Nesse sentido, os danos que incidem sobre direitos que a ordem jurídica escolheu tutelar são reputados ilícitos. (STANZIONE, 2013, p. 790).

Ressalte-se que, em relação ao resultado danoso, é suficiente o elemento objetivo do ilícito, ou seja, a contrariedade ao Direito, pois a voluntariedade está na conduta, sendo o dano sempre um resultado. Dito de outra forma: para que o resultado danoso seja qualificado como ilícito, é suficiente a contrariedade ao Direito, pois não há culpa no resultado, apenas na conduta. Mesmo que o dano seja desejado pelo agente em determinadas situações, a voluntariedade está sempre localizada na conduta.

Assim, a conduta (lícita ou ilícita) produz um evento danoso, o qual será considerado ilícito sempre que revelar a lesão de um direito subjetivo ou de interesse juridicamente relevante, denominando-se "dano evento", além de um prejuízo econômico que normalmente a ele se associa como consequência material intitulado "dano consequência", sendo esse o sentido jurídico de dano, que será melhor analisado nos próximos parágrafos.

Esses dois aspectos do dano são indispensáveis para a sua compreensão, já que, conjuntamente, são determinantes da responsabilidade civil, inclusive aplicada ao Estado. Afirma Renato Alessi: "la lesione deve essere, oltreché lesione della sfera economica, lesione della sfera giuridica: il che trasforma il mero danno economico in un danno giuridico, come tale risarcibile”. (ALESSI, 1972, p. 8).

Não fosse a necessidade de aferir a presença do componente ilícito no dano, que corresponde à lesão de direitos subjetivos ou de interesses juridicamente protegidos, para a existência do dever de ressarcir, que confere sentido jurídico ao dano, seria possível concluir equivocadamente que basta uma perda qualquer, o dano em sentido comum, entendido como a sensação subjetiva de quem sofre com a conduta alheia, para que haja responsabilidade.

Por exemplo, a situação do candidato a uma vaga de emprego que mora em Salvador e, para realizar uma entrevista num famoso escritório de São Paulo, adquire 
passagem aérea, gasta com hospedagem e transporte. Se o candidato não for aprovado na entrevista e, consequentemente, contratado pelo escritório, terá sofrido danos que equivalem às despesas acima descritas, todavia, não terá direito ao ressarcimento, pois não houve violação a interesses protegidos pelo ordenamento jurídico ou a direitos subjetivos.

Dessa maneira, não basta que a suposta vítima se considere lesada, é necessário que o dano seja reputado relevante pela sociedade, isto é, que traduza a lesão dum direito subjetivo ou de interesse juridicamente protegido, pois é o que determina a contrariedade ao Direito, além do dano econômico. (STANZIONE, 2013, p. 789).

Sobre o tema, conclusiva a afirmação de Fernando Dias Menezes de Almeida: "dano, para fins de responsabilidade civil, é aquilo que o direito objetivamente considera e não aquilo que a vítima subjetivamente assim considera". (ALMEIDA; CARVALHO FILHO, 2014, p. 396).

3. Requisitos da Responsabilidade do Estado por dano tributário segundo o Direito brasileiro vigente

Para deflagrar tal responsabilidade, requer-se a presença dos elementos estabelecidos em lei (art. 37, § $6^{\circ}$ da CF e arts. 927 e 186 do CC), considerados essenciais, sem os quais não há dever de ressarcimento. São eles: i) conduta (lícita ou ilícita) do agente público; ii) dano ilícito; e, iii) nexo de causalidade entre a conduta do agente público e o dano.

\subsection{Conduta}

Conduta é o comportamento humano comissivo (positivo) ou omissivo (negativo) que produz dano por uma relação de causalidade. Para o Direito, trata-se somente da ação ou omissão impulsionada pela psique ou, como se convencionou dizer, da ação ou omissão voluntária, que se refere à participação decisiva do ser humano na ocorrência do evento. (MARQUES, 1955, p. 41).

No que se refere ao exercício da função fiscal, o agente público realiza diversas condutas comissivas (positivas) capazes de produzir danos ao contribuinte (ou responsável), sendo a primeira delas a constituição do crédito tributário por meio do ato de lançamento, cuja realização é obrigatória e vinculada sempre que for praticado o fato gerador que se enquadra na previsão legal.

Com base nos arts. 147 a 150 do CTN, há três espécies de lançamento: i) de ofício, ii) por declaração e iii) por homologação. O lançamento de ofício corresponde ao ato formalizador que é realizado por iniciativa da autoridade administrativa, a quem cabe verificar a ocorrência do fato gerador, identificar o sujeito passivo, calcular o montante devido e notificá-lo para o pagamento, segundo o art. 149 do CTN. O IPVA e o IPTU 
costumam ser tratados por suas leis instituidoras como tributos sujeitos a lançamento de ofício.

O lançamento por declaração está condicionado às informações prestadas pelo contribuinte para que a obrigação seja formalizada, conforme o art. 147 do CTN. Nesse caso, o contribuinte e o Fisco concorrem para o lançamento, cabendo ao primeiro apresentar as declarações e ao segundo calcular o montante devido.

Não é a declaração que caracteriza tal espécie de lançamento, mas a circunstância de que é o Fisco quem calcula o valor do tributo com base nas declarações prestadas pelo contribuinte. Pode ser mencionado como exemplo dessa categoria de lançamento tributário o imposto sobre a transmissão causa mortis e doação (ITCMD).

O lançamento por homologação ou "autolançamento", em que o próprio sujeito passivo da relação tributária verifica a ocorrência do fato gerador, calcula o montante devido e faz o pagamento, sem o exame prévio da autoridade fiscal, é a modalidade de lançamento sujeita a controle pelo Fisco (a posteriori) em caráter supletivo, se houver irregularidades. Está sujeito a condição resolutória concernente à posterior homologação, nos termos do art. 150 do CTN, podendo citar como exemplo o imposto sobre a renda (IR), o imposto territorial rural (ITR), o imposto sobre circulação de mercadorias e serviços (ICMS) e imposto sobre serviços (ISS).

Por coerência à necessidade de atuação administrativa, nos termos do art. $3^{\circ}$ do CTN, o desembolso do contribuinte não pode ser considerado definitivo. Logo, é a antecipação de algo que ainda precisará ser apurado posteriormente. Se concluir que o pagamento corresponde ao valor exigível, o Fisco "homologa" expressamente "o pagamento antecipado", segundo o art. 150 do CTN. Essa homologação também pode ser tácita, pois o silêncio do Fisco tem o mesmo sentido de sua concordância. No caso de discordância dos valores apurados e pagos pelo contribuinte, deverá notificá-lo do débito e das penalidades aplicadas por meio do lançamento de ofício. (SCHOUERI, 2014, p. 612).

Ensina James Marins que a diferença entre as espécies de lançamento está no grau de efetiva contribuição do sujeito passivo para sua realização. Nos lançamentos por declaração e por homologação, quem de regra cumpre o encargo de registar de maneira detalhada as condições da incidência tributária minudenciando seus efeitos é o próprio contribuinte; ao passo que, no lançamento de ofício, compete exclusivamente à Administração Tributária a prática de toda a sequência de atos. (MARINS, 2015, p. 205).

Nos casos em que a lei impõe a obrigação do contribuinte de apurar e pagar o tributo, o lançamento de ofício possui caráter supletivo, visto que o Fisco atua quando o contribuinte não o faz, ou não o faz de maneira satisfatória, deixando não apenas de efetuar o pagamento do montante devido, mas de depositá-lo ou declará-lo adequadamente. Por consequência, se não for homologado o lançamento do contribuinte, a Administração 
Tributária deverá cientificá-lo e intimá-lo para que, no prazo de 30 dias, pague o valor devido ou apresente impugnação suspendendo a exigibilidade do crédito tributário em via administrativa, sob pena de inscrição do débito em dívida ativa e do prosseguimento em execução fiscal.

No que tange ao ressarcimento de danos, nos casos em que a lei impõe que o lançamento seja feito pelo contribuinte, vale dizer, no lançamento por homologação ou "autolançamento", o ato que identifica a conduta causadora do dano é praticado pela Administração Tributária, não pelo contribuinte, isto é: trata-se do lançamento de ofício de caráter supletivo, pois a responsabilidade do Estado depende de uma conduta estatal, ou seja, praticada pelo agente público, que pode ser uma ação ou omissão da qual resulte o efeito danoso na esfera jurídica de terceiro, que é o sujeito passivo da relação tributária, de forma que a mera consumação do dano em sua órbita individual, ou do dano resultante de ato por ele mesmo praticado, é insuficiente para que se verifique o dever de ressarcimento.

Essa ideia confirma-se nos arts. 186 e 927 do CC, que utilizam a expressão “causar dano a outrem", pois é justamente em razão do fato de existir um terceiro que se dá o dever de ressarcimento. Logo, com base na noção jurídica, o dano deve ser relevante, tutelável pelo Direito e causado por um sujeito diverso daquele que o sofreu.

O lançamento tributário pode ensejar a prática de outros atos que caracterizam uma ameaça concreta ao patrimônio do contribuinte, tais como: auto de infração, inscrição do débito em dívida ativa, indeferimento de certidão negativa de débito fiscal, inscrição no CADIN, indisponibilidade de bens e de direitos, ajuizamento da execução fiscal etc.

São considerados de maior relevância no exercício da função fiscal os seguintes atos: i) lançamento de ofício e "autolançamento"; ii) ato de revisão da atividade do contribuinte ("lançamento e imposição de multa"); iii) inscrição em dívida ativa; e, iv) ato de ajuizamento de execução fiscal. Como se inserem na categoria dos atos administrativos, devem obedecer inteiramente aos parâmetros estruturais estabelecidos pela lei. Não preenchido qualquer desses pressupostos, será um ato maculado por vícios que impedem a sua subsistência, sendo, portanto, ilegítimos e passíveis de invalidação pela própria Administração Tributária, segundo o art. 145 do CTN, ou pelo Poder Judiciário, por meio de ação judicial. Se com a anulação do ato praticado pelo Fisco recompõe-se a ordem jurídica, não há que se falar em responsabilidade do Estado.

Os atos relacionados no parágrafo anterior podem compor a conduta causadora do dano tributário, por isso se submetem às regras a seguir que esclarecem a conduta como elemento da responsabilidade do Estado.

Como espécies do gênero ato administrativo, o lançamento e os demais atos que constituem a função fiscal obedecem ao regime jurídico de Direito Administrativo e aos rigores próprios da atividade tributária. Desse modo, eventuais vícios de fiscalização 
e constituição contaminam sua validade, tornando-o ilegítimo e passível de anulação. A sujeição à lei impõe que os atos administrativos sejam praticados em acordo com o padrão estabelecido pela lei como condição de existência e validade do ato, isto é: i) agente competente, ii) objeto lícito e possível, iii) forma prescrita em lei, iv) motivo conforme o interesse público e v) finalidade pública, sob pena de invalidação. (DI PIETRO, 2011, p. 210).

Significa dizer que o ato deve resultar do exercício das atribuições de um agente público competente, que recebeu poderes para realizar aquela parcela da função administrativa sob pena de apresentar vício relativo ao sujeito que o torna ilegítimo e, portanto, passível de anulação. A título de exemplo: o lançamento de imposto sobre a propriedade predial e territorial urbano (IPTU) relativo a imóvel situado no Município de Barueri por um fiscal municipal vinculado ao Município de São Paulo como se fosse o agente competente para emitir a cobrança.

Ademais, o objeto e o conteúdo do ato devem ser lícitos, ou seja, o resultado que se pretende alcançar deve estar pautado em lei, ser possível - física e juridicamente -, certo e determinado, além de razoável e moral. Nos atos vinculados, que constituem a maior parte dos atos no exercício da função fiscal, o objeto está determinado no preceito legal, razão pela qual: se é proibido pela lei, diverso do que foi previsto para o caso sobre o qual incide ou impossível, imoral ou incerto, há vício relativo ao objeto, requerendo sua anulação.

Por exemplo: no lançamento tributário relativo à cobrança de contribuição social sobre o lucro, a autoridade administrativa mal interpreta a lei, elaborando cálculos com base no faturamento da empresa; ou, ao exigir o imposto territorial rural (ITR), adota base de cálculo superior à devida, o que significa a não ocorrência do fato gerador conforme a previsão da hipótese de incidência. Se no termo de inscrição do débito em dívida ativa não existe indicação do nome do devedor e dos corresponsáveis, da quantia devida e do modo de calcular os juros de mora, nos termos do art. 202 e 203 do CTN, poderá ser declarada a nulidade do ato em razão da falta de certeza em relação a seu objeto, considerando-o ilegítimo.

Outro exemplo relacionado ao vício do objeto - lícito, possível e determinado - é o lançamento feito pela autoridade fiscal desconsiderando a sentença transitada em julgado proferida em ação declaratória aforada pelo contribuinte em face da Fazenda Pública com a finalidade de ver reconhecida judicialmente a existência ou a inexistência de determinado vínculo jurídico-obrigacional de caráter tributário a fim de promover o acertamento da relação jurídica maculada pela incerteza.

$\mathrm{O}$ ato é ilegal por vício de forma se a lei a exige de forma expressa ou se a finalidade só pode ser alcançada por aquela forma específica. Em matéria fiscal, a constituição do crédito fiscal pelo lançamento ou auto de infração e a emissão da certidão 
de dívida ativa, por exemplo, exigem o cumprimento de formalidades sob pena de invalidade do ato, nos termos dos arts. 142 e 202 do CTN.

Deve constar no lançamento referência clara aos elementos do art. 142 do CTN, identificando o fato gerador, a matéria tributável, o montante devido, o sujeito passivo, a penalidade cabível, fazendo-se necessária inclusive a indicação inequívoca e precisa da norma tributária impositiva incidente.

Se há vício formal no lançamento, invalida-se a constituição do crédito tributário, o que não afeta a obrigação tributária, pois novo lançamento poderá ser efetuado antes de expirado o prazo decadencial, sempre com base na produção de nova linguagem.

Em relação ao motivo, para Paulo de Barros Carvalho, é o acontecimento do mundo que feriu a sensibilidade de sujeito de direito e que está à espera da linguagem própria que lhe dê foros de objetividade. Logo, está atrelado aos fundamentos que ensejam a celebração do ato. Como exemplo de ilegitimidade do ato administrativo capaz de tornálo nulo por vício de motivação, sugere o lançamento cujo motivo nele inscrito, isto é, a ocorrência do fato jurídico-tributário, nunca aconteceu. (CARVALHO, 2011, p. 467).

Ou seja, o caso em que a Administração Tributária prosseguiu em execução fiscal para cobrar débito tributário contra o suposto devedor lastrado em certidão de dívida ativa (CDA) relativa a lançamento de IPTU em relação a imóvel que não era de sua propriedade, mas de propriedade do próprio Município. Além de ilegítimo por vício de motivação, pois o fato gerador não foi praticado, nota-se que a conduta do agente público é visivelmente culposa, caracterizando erro grosseiro. Para finalizar, há vício de finalidade sempre que o agente público praticar o ato visando fim diverso daquele previsto explicita ou implicitamente na regra de competência. ${ }^{1}$

\subsubsection{Conduta ilícita}

A conduta é ilícita se, além da ilegitimidade do ato, ou seja, da contrariedade ao Direito que decorre da presença de vícios que causam a sua invalidação, conforme discutido no tópico anterior, há culpa lato sensu do agente público, composta pela violação intencional do dever jurídico que caracteriza o dolo e pelo descumprimento do dever de diligência marcado pela imprudência, negligência e imperícia no agir administrativo (culpa stricto sensu), podendo causar danos que traduzem a violação de direitos subjetivos do cidadão.

O descumprimento do dever de diligência pode ser identificado pela inobservância dos princípios tributários e administrativos dispostos em âmbito

BRASIL. Superior Tribunal de Justiça. Recurso Especial n. 1.139.492/PB. Rel. Min. Mauro Campbell Marques. j. 17/5/2011. 
constitucional e infraconstitucional, que atuam como parâmetro para atuação dos agentes públicos ao regular o modus operandi da Administração Tributária, isto é: legalidade, impessoalidade, moralidade, publicidade, eficiência, igualdade, capacidade contributiva, anterioridade, boa-fé, irretroatividade, não confisco, colaboração, transparência, razoabilidade, proporcionalidade etc., cuja lesão revela a culpa do agente público no exercício de sua atividade.

No art. 186 do CC, o legislador define ato ilícito, estabelecendo como elementos: i) ação ou omissão; ii) culpa (sentido amplo); iii) violação de direito (antijuridicidade); e, iv) dano. Dispõe o referido artigo: “aquele que, por ação ou omissão voluntária, negligência ou imprudência, violar direito e causar dano a outrem, ainda que exclusivamente moral, comete ato ilícito". (Grifo nosso).

Com base na leitura do dispositivo, constata-se que o ato ilícito é a manifestação de vontade, dolosa ou culposa, que viola direito e causa dano. (AZEVEDO, 2011, p. 61). Afirma Francisco do Amaral: "no Direito brasileiro, o ato ilícito exige a conjugação dos elementos: ação ou omissão do agente, ilicitude, culpa, nexo causal e dano". Porém, não existe unanimidade em relação à definição de ato ilícito, particularmente no que se refere à inclusão do dano entre seus elementos essenciais. (AMARAL, 2006, p. 148-149).

Para Rui Stoco, no art. 186 do CC, o legislador cometeu um equívoco ao considerar o dano como parte integrante do ilícito ao prescrever que "comete ato ilícito aquele que viola direito e causa dano". Isso porque é possível que alguém cometa um ato ilícito sem necessariamente causar dano a outrem e, consequentemente, sem que exista o dever de reparação. Assim, o dano não pode ser considerado um elemento do ilícito, mas tão somente da responsabilidade. Esclarece: "só a violação do direito já caracteriza o ato ilícito". (STOCO, 2011, p. 142).

Segundo Carlos Roberto Gonçalves, a conjunção aditiva "e" foi usada pelo legislador no art. 186 do CC não para incluir o dano como elemento do ilícito, mas para demonstrar que não há dever de ressarcir nas hipóteses em que, mesmo com a infração do dever jurídico de agir diligentemente, não houver prejuízo. (GONÇALVES, 2009, p. 454).

Sobre o tema, assevera San Tiago Dantas que: "o ilícito é a transgressão de um dever jurídico. Não há definição mais satisfatória para o ilícito civil”. (DANTAS, 1983, p. 345).

Por tal viés, intitulado objetivo, o ato ilícito revela a antijuridicidade da conduta, isto é, a objetiva violação do dever jurídico, questão sobre a qual não existe divergência entre os doutrinadores. Conforme afirma Sergio Cavalieri Filho: "todos estão de acordo em que o cerne da ilicitude consiste, precisamente, em ser o fato - evento ou conduta - contrário ao Direito, no sentido de que nega os valores e os fins da ordem jurídica". (CAVALIERI FILHO, 2014, p. 22). 
O outro viés do ato ilícito refere-se ao seu aspecto subjetivo, que corresponde à culpa do sujeito que praticou a conduta, manifestada na vontade dirigida a realizar os elementos da situação fática (dolo) ou na violação de dever de conduta diligente preestabelecido num tipo abstrato dentro das condições do caso concreto (culpa).

Segundo Álvaro Villaça Azevedo, os pressupostos fundamentais do ato ilícito residem na contrariedade ao direito, ou seja, na infração de normas jurídicas, que constitui o seu pressuposto objetivo, como também em ter sido previsível ou afastável o resultado, isto é, a culpa lato sensu. (AZEVEDO, 2011, p. 61).

Assim, com base na noção de ato ilícito atribuída pelo legislador no art. 186 do CC, para que a conduta seja ilícita, além da contrariedade ao Direito, ou seja, da antijuridicidade, é necessária a presença da culpa lato sensu, caso contrário, não há ato ilícito, mas apenas ato antijurídico, desde que não exista causa de justificação. No âmbito dos atos administrativos, o ato desconforme ao Direito é denominado ato ilegítimo. Nesse sentido, a contrariedade ao Direito, isoladamente, não é suficiente para caracterizar a ilicitude da conduta, embora seja para indicar a ilicitude do dano.

Considera-se que o dano não é parte integrante do ato ilícito, mas realidade autônoma a ser verificada em cada caso concreto. Isso porque não é certo que da violação das normas jurídicas resulte necessariamente danos passíveis de ressarcimento: pode haver somente a ilegitimidade, a ilegalidade, associada à culpa. Se com a anulação do ato praticado pela Administração Pública repõe-se a ordem jurídica, não há responsabilidade do Estado.

A esse respeito, esclarece Mario Bessone que, nas hipóteses em que se aplica a responsabilidade objetiva, não parece aceitável afirmar a ideia de que o dano é parte integrante do ilícito, visto que a responsabilidade é admitida mesmo no caso de condutas lícitas. Logo, ilícito e responsabilidade são coisas diversas, pois pode haver responsabilidade sem ilícito bem como ilícito sem responsabilidade. (BESSONE, 2000, p. 62).

3.1.1.1. A aplicação das teorias objetiva e subjetiva à responsabilidade do Estado por dano tributário

A partir da leitura do art. 927 do CC, constata-se que o ordenamento jurídico brasileiro adotou duas espécies de responsabilidade: subjetiva e objetiva. No caput do artigo, foi estipulada a responsabilidade subjetiva, considerada regra geral do Direito brasileiro, cujo requisito essencial é a presença da conduta ilícita, dentro da qual se insere a culpa lato sensu e a desconformidade com o Direito; e, no parágrafo único, a responsabilidade objetiva. 
Apesar de a teoria objetiva da responsabilidade - também denominada "responsabilidade sem culpa" e "responsabilidade pelo resultado" - ser a espécie predominantemente aplicada à responsabilidade do Estado por danos tributários, pois foi estampada no $\S 6^{\circ}$ do art. 37 da $\mathrm{CF}$, a teoria subjetiva é empregada em duas situações, as quais serão analisadas a seguir, vale dizer: nas hipóteses em que o dano resulta de uma conduta omissiva do agente público e à eventual ação de regresso movida pelo Estado contra o agente causador do dano.

Para a teoria subjetiva, a responsabilidade civil assenta-se nos seguintes pressupostos: i) dano, ii) culpa lato sensu de seu autor e contrariedade ao Direito (conduta ilícita) e iii) nexo de causalidade entre a conduta e o dano. Chega-se a essa conclusão pela interpretação dos arts. 186, 187 e 927 do CC. É necessário que o lesado demonstre a culpa lato sensu do sujeito que causou o dano, pois o foco da responsabilidade recai sobre a valoração da conduta. Em tal caso, a ilicitude da conduta macula o dano, tornando-o automaticamente ilícito.

Há infração de um dever preexistente de forma intencional (dolo) ou com negligência, imprudência ou imperícia (culpa), que viola um direito subjetivo individual produzindo o resultado danoso, o qual, por sua vez, se relaciona ao descumprimento de outra norma jurídica que impõe o dever geral de "não causar danos a ninguém".

No que se refere à teoria objetiva, por reconhecer a vulnerabilidade do lesado em certas situações, o legislador determinou no parágrafo único do art. 927 do CC e no $\S 6^{\circ}$ do art. 37 da CF que o dever do agente causador do dano de ressarci-lo independe da demonstração da culpa lato sensu, sendo suficiente a prova da ocorrência do dano e do nexo casual entre o dano e a conduta, sem prejuízo de eventuais excludentes trazidas pelo Poder Público. Nessa situação, o foco da responsabilidade é transferido da valoração da conduta ao prejuízo sofrido pela vítima.

Constata-se que, tanto na responsabilidade subjetiva quanto na responsabilidade objetiva a causa do dano pode ser uma conduta ilícita. Diferem-se essas espécies de responsabilidade porque, na primeira, há dever de ressarcir somente quando o dano tiver como causa a conduta ilícita, conforme o caput do art. 927 do CC combinado com o art. 186 do CC; ao passo que, na segunda, a causa do dano pode ser a conduta lícita e a ilícita, segundo o parágrafo único do art. 927 do $\mathrm{CC}$ e, no que tange à responsabilidade do Estado, o $\S 6^{\circ}$ do art. 37 da CF.

Logo, apesar da responsabilidade objetiva prescindir da prova da culpa lato sensu, não significa que o dano não possa resultar também da prática da conduta ilícita. Pelo contrário, por meio da pesquisa jurisprudencial realizada nos Tribunais brasileiros, verificou-se que, na maioria das vezes, o dano resulta de ato ilegítimo praticado pelo agente público como consequência do descumprimento do dever de diligência que lhe é imposto em razão da natureza da atividade estatal. 
Situação que ocorre com certa frequência, constituindo a maior parte das ações judiciais propostas pelos contribuintes perante o Poder Judiciário refere-se à exigência tributária flagrantemente ilegal - em relação à obrigação principal, cujo objeto é o pagamento de tributo ou penalidade pecuniária (multa), e à obrigação acessória, isto é, das prestações positivas ou negativas previstas no interesse da arrecadação ou fiscalização dos tributos.

Nesses casos, normalmente, verifica-se um erro grosseiro do agente público que revela negligência ou imprudência no desempenho da função fiscal, as quais determinam da ilicitude da conduta, explicitando a lesão de princípios constitucionais administrativos e tributários que disciplinam o modus operandi do agir administrativo em matéria fiscal, por exemplo: i) falta de regularização dos cadastros do Fisco pelo agente público que deixa de alterar o CPF/MF do novo proprietário do veículo automotor junto ao DETRAN após a transferência do veículo e a regular comunicação efetuada na época da venda, ensejando a cobrança de IPVA ao antigo proprietário, protesto da CDA e inserção de nome no $\mathrm{CADIN}^{2}$; ii) o ajuizamento de execução fiscal para cobrança de IPTU em face de pessoa física em relação a imóvel cuja propriedade era do próprio Município exequente $^{3}$ e de IPTU de imóvel que foi objeto de desapropriação pelo Município há mais de 10 anos; ${ }^{4}$ e iii) execução fiscal promovida em face de um homônimo do contribuinte sem conferência do CPF/MF ou CNPJ etc. ${ }^{5}$

É importante observar que não é necessário que seja ajuizada a execução fiscal para que se configure a ilicitude do agir do Fisco. O mero lançamento tributário ou o auto de infração em relação a "crédito" fiscal cujo pagamento havia sido efetuado é suficiente para caracterizar a conduta ilícita e viabilizar a responsabilidade do Estado se há danos como o ajuizamento de ação anulatória de débito fiscal que requer seja realizado o depósito do montante integral para a suspensão da exigibilidade do crédito tributário, além dos gastos para a contratação de profissionais bem como com o processo judicial etc.

No julgamento do REsp n. 773.470/PR, 2 ${ }^{\mathrm{a}}$ Turma, em 02/03/2007, de relatoria da Ministra Eliana Calmon, reconheceu-se que, nas execuções fiscais indevidas, o dano moral é presumido, ou seja, é considerado in re ipsa. Tal posicionamento foi mantido por ocasião do julgamento do AgRg no Ag n. 1163561/RJ, em 20/04/2010,

2 BRASIL. Tribunal de Justiça do Estado de São Paulo. Apelação n. 0002912-39.2014.8.26.0370. Rel. Des. Oscild L. Júnior. Jul. 3/6/2016.

3 BRASIL. Superior Tribunal de Justiça. Recurso Especial n. 1.139.492/PB. Rel. Min. Mauro Campbell Marques. Brasília. J. 17/5/2011.

4 BRASIL. Tribunal de Justiça do Estado de São Paulo. Apelação Cível n. 0002382-87.2014. Rel. Des. Mauro C. Marques. J. 26/9/2016.

5 BRASIL. Tribunal Regional Federal $3^{\text {a }}$ Região. Apelação n. 1905302/SP. Rel. Des. Federal Antonio Cedenho. J. 2/9/2016. 
sendo reproduzido em casos semelhantes, desde então, não só pelo STJ, mas por tribunais regionais brasileiros.

A descabida exigência do tributo - tal como nas situações anteriormente mencionadas - caracteriza a conduta como ilícita: em primeiro lugar, em razão da ilegalidade da cobrança, já que não foi praticado o fato gerador pelo sujeito apontado como devedor no ato de lançamento, no auto de infração ou na execução fiscal; e, em segundo, da culpa lato sensu pela negligência do agente público que deixou de atualizar os cadastros do Fisco e de dar baixa nos pagamentos; ou, pela imprudência em indicar como executado um homônimo do devedor e não o próprio devedor.

Como tal situação se enquadra na regra geral da responsabilidade do Estado cuja teoria aplicada é a objetiva - pois a teoria subjetiva se aplica apenas se o dano resulta de condutas omissivas do agente público ou na ação de regresso movida pelo Estado contra o agente que agiu com dolo ou culpa - o lesado está livre de demonstrar a culpa lato sensu do agente público na realização da conduta, mas não está livre de provar que o ato administrativo que produziu o dano é ilegítimo - e, portanto, inválido -, indicando a contrariedade do ato com a ordem jurídica.

A ilicitude da conduta, por si só, confere o caráter ilícito ao resultado danoso; mas, constata-se que o próprio dano revela a lesão de direitos do contribuinte, como o direito à propriedade e liberdade, além do direito de que o exercício da função fiscal seja efetuado em acordo com os princípios constitucionais, administrativos e tributários. Logo, a violação desses direitos caracteriza a ilicitude do dano.

A atuação do Fisco em conformidade com os princípios constitucionais administrativos e tributários constitui um direito subjetivo de cada contribuinte (ou responsável) de modo que o dano decorrente de sua violação é visivelmente ilícito. Ademais, os princípios auxiliam na interpretação das regras jurídicas para a verificação da ilegalidade do ato e sobretudo como um parâmetro para aferir o descumprimento do dever de diligência pelo agente público, ou seja, sua culpa em sentido amplo.

Constata-se que o contribuinte está sujeito a inúmeros danos em razão da ilegalidade e da culpa lato sensu na atuação do Fisco, por exemplo: i) a realização de defesa administrativa e, em caso de insucesso, em via judicial, ficando ameaçado de ser submetido à execução fiscal com a possibilidade de ter seus bens bloqueados e obstando a expedição de certidão negativa de débitos se não for realizado o depósito do valor do montante integral do débito ou se não for deferida liminar para suspensão da exigibilidade do crédito tributário, segundo o art. 151, incisos II e III do CTN; ii) impedimento de participar de procedimentos licitatórios (art. 195, $\S 3^{\circ}$ da CF); iii) impossibilidade de obter empréstimos bancários e outras situações nas quais a ausência de certidão negativa de débito fiscal implica sérios prejuízos para as atividades empresariais. 
Logo, outro aspecto do dano é o prejuízo econômico efetivamente sofrido, tais como os gastos com a contratação de advogados, assistentes técnicos e as despesas processuais, a impossibilidade de efetuar transações em razão do bloqueio de contas bancárias e da negativa de crédito junto às instituições financeiras, que impedem as atividades empresariais ensejando o descumprimento de contratos firmados com clientes, a aplicação de multas, a perdas de clientes, etc.

Considera-se culposa e, por isso, ilícita, a conduta do agente público de lançar obrigação tributária, lavrar o auto de infração, inscrever o débito em dívida ativa e ajuizar execução fiscal nos casos em que tais atos versem sobre a mesma questão jurídica discutida, mas são praticados em sentido contrário, em desconformidade com os entendimentos consolidados favoráveis ao contribuinte proferidos pelo STF em Controle Concentrado de Constitucionalidade, em Recursos Extraordinários com repercussão geral reconhecida, Súmulas Vinculantes; e, em decisões proferidas pelo STJ em Recursos Especiais, obedecendo à sistemática dos arts. 543-B e 543-C do CPC/73, os quais correspondem aos arts. 1.036 e 1.041 do NCPC. (SANTI; SCAPIN, 2014, p. 1).

Para James Marins, a Receita Federal do Brasil e seus órgãos vinculados não podem divergir do posicionamento das Cortes nesses casos, por isso devem: i) deixar de promover o lançamento de créditos tributários que apresentem discussão judicial favorável aos contribuintes; ii) anular cobranças formalizadas; e, iii) promover a restituição ou a compensação por cobranças reconhecidas como indevidas pelo Poder Judiciário. (MARINS, 2015, p. 244).

Tal procedimento é relevante por diversos motivos, dentre os quais por garantir: i) uniformidade, igualdade e segurança na aplicação do Direito; ii) tratamento isonômico na aplicação administrativa para casos semelhantes; iii) critérios de legalidade para a realização da atividade plenamente vinculada de constituição e de cobrança do crédito tributário; bem como para: iv) prevenir discrepâncias entre a atuação do Fisco no exercício da arrecadação e da fiscalização dos tributos e os precedentes das Cortes brasileiras; v) aumentar o grau de respeito das decisões judiciais, tornando a ação da Administração Tributária mais coerente; vi) gerar confiança entre Fisco e contribuinte; e, v) evitar gastos inúteis, seja pelo contribuinte para enfrentar longos processos judiciais repletos de recursos, seja pelo ente público.

Desse modo, é ilícita a conduta do agente público de constituir o crédito fiscal, inscrever o débito em dívida ativa e prosseguir em execução fiscal em desconformidade com entendimento do STF e do STJ nas situações acima referidas. Além de constituir violação ao Direito, sobretudo em razão dos interesses perseguidos pela norma, há culpa lato sensu dada a inobservância da interpretação da norma aplicável ao caso concreto, o que caracteriza o descumprimento do dever de diligência. 
Nesse mesmo sentido, a Instrução Normativa da Receita Federal do Brasil n. 1.434/13, publicada em 2 de janeiro de 2014, que deu nova redação à Instrução Normativa n. 1.396/13, por meio da qual a Receita Federal afirmou expressamente o efeito vinculante das Soluções de Consulta e das Soluções de Divergência emitidas pela Coordenação Geral de Tributação (COSIT), órgão ao qual são dirigidas as consultas acerca da interpretação da legislação tributária e aduaneira, que já era um posicionamento aplicado pela doutrina e pela jurisprudência. ${ }^{6}$

Trata-se duma relevante declaração que permite considerar ilícitas as condutas dos agentes públicos incompatíveis com o que foi enunciado nas consultas, em âmbito federal, permitindo imputar a responsabilidade ao Estado pela contrariedade à norma jurídica, que prevê o efeito vinculante que impõe a aplicação da interpretação constante na consulta, somada à culpa do agente que deixou de cumpri-la por dolo, negligência, imprudência ou imperícia.

Essa observação torna-se relevante para o presente estudo dada a existência dum precedente do STF de notável importância que se relaciona à condenação da Administração Tributária a ressarcir os danos causados ao contribuinte porque a resposta dada na consulta contendo o entendimento do Fisco sobre a correta interpretação da norma era incompatível com o praticado em relação aos demais contribuintes na mesma situação.

Com o propósito de elucidar o momento próprio da incidência dum imposto (ao ser expedida a nota fiscal para a entrega futura ou a real saída dos produtos industrializados) e para alcançar a "certeza administrativa-tributária", o contribuinte formulou uma consulta ao Fisco, passando a pagar o tributo nos moldes da interpretação indicada a respeito da temática (emissão da nota fiscal para entrega futura).

Entretanto, ulteriormente, constatou que as outras empresas do mesmo ramo de atividade econômica efetuavam o recolhimento da referida exação de forma absolutamente distinta e bem menos onerosa (a real saída dos produtos industrializados). Por isso, o contribuinte realizou uma segunda consulta sobre a mesma matéria que foi respondida pelo mesmo consultor tributário, mas em sentido diametralmente oposto.

Como o fato provocou prejuízos, sobretudo dada a alta inflação, foi proposta ação de ressarcimento de danos pelo contribuinte. No Recurso Extraordinário n. 131.7418/SP, julgado em 9 de abril de 1996, que teve como relator o Ministro Marco Aurélio Mello, entendeu-se que: i) o instituto da consulta tributária não se mostra informal, estando previsto em vários regulamentos, dentre os quais nos arts. 540 a 556 do Regulamento

BRASIL. Instrução Normativa da Receita Federal do Brasil n. 1.434/13. "Art. 9. A solução de Consulta Cosit e a Solução de Divergência, a partir da data de sua publicação, têm efeito vinculante no âmbito da RFB, respaldam o sujeito passivo que as aplicar, independentemente de ser o consulente, desde que se enquadre na hipótese por elas abrangidas, sem prejuízo de que a autoridade fiscal, em procedimento de fiscalização, verifique seu efetivo enquadramento". 
do Imposto Sobre a Circulação de Mercadorias e Serviços, sujeitando o contribuinte à lavratura de auto de infração e às penalidades aplicáveis em caso de descumprimento; e, ii) a relação jurídica estabelecida entre o Estado e o contribuinte deve repousar, sempre, na confiança mútua, devendo ambos atuarem com responsabilidade, fiéis ao Direito em vigor. $^{7}$

Nesse sentido, como o contribuinte adotou postura de absoluta boa-fé - pois: i) fez consulta ao Fisco; ii) agiu em conformidade com a resposta obtida, que implicou graves danos, pois as empresas congêneres atuavam em modo diverso; iii) formulou segunda consulta, mediante a qual o Fisco modificou a postura anterior admitindo como correto a prática das demais empresas - julgou-se procedente o pedido de ressarcimento de danos com base no argumento de que a Administração Tributária tem o dever de assumir as consequências dos erros cometidos, que, no caso, implicaram em inegável vantagem ao Estado, bem como em danos ao contribuinte, razão pela qual deve indenizá-los a partir da data em que foi obtida a resposta.

Conforme é possível constatar, o contribuinte sofreu danos devido aos pagamentos efetuados antes das datas em que deveriam ter sido efetivamente feitos, pois a empresa ficou privada da disponibilidade do dinheiro pelo tempo em que ocorreu a antecipação, perdendo a remuneração correspondente que, naquela época, não era irrelevante em razão da constante desvalorização da moeda.

Outra relevante situação que caracteriza a conduta ilícita é o abuso de direito regulado no art. 927 do CC que o define como fato gerador da obrigação de indenizar ao estabelecer: "aquele que, por ato ilícito (arts. 186 e 187), causar dano a outrem, fica obrigado a repará-lo", e conceituado no art. 187 do CC: "também comete ato ilícito o titular de um direito que, ao exercê-lo, excede manifestamente os limites impostos pelo seu fim econômico ou social, pela boa-fé ou pelos bons costumes". Como se pode depreender da leitura de tais dispositivos, no Direito brasileiro, o abuso de direito é tratado como ato ilícito, sendo suas consequências as mesmas do ato ilícito.

Contudo, não se trata de ofensa frontal ao direito de outrem, nem da violação a uma norma que tutela interesse alheio, como normalmente ocorre com os atos ilícitos, mas do exercício anormal do direito. Extrapola-se os limites do direito causando prejuízo a outrem, isto é, a conduta está respaldada na lei, mas fere ostensivamente seu espírito. Nesse sentido, os danos resultantes do abuso de direito merecem ser ressarcidos, visto que consistem na violação aos princípios de finalidade da lei e equidade, pois se afastam da ética, da boa-fé, da finalidade social ou econômica do direito, o qual é exercido, na situação concreta, sem motivo legítimo.

BRASIL. Supremo Tribunal Federal. Recurso Extraordinário n. 131.741-8/SP. Relator Ministro Marco Aurélio Mello. J. 9/4/1996. 
O STJ imputou a responsabilidade ao Estado por dano tributário em decorrência de conduta ilícita por abuso de direito por considerar abusivo o prosseguimento da ação por parte da Fazenda Pública, inclusive com a apresentação de recurso especial, quando todos os documentos prontamente juntados nos autos pelo cidadão deixavam claro que o executado não era o proprietário do imóvel objeto da tributação. Declarou-se que, embora assegurado em âmbito constitucional, o direito de petição foi usado de forma abusiva, configurando ato ilícito passível de indenização nos termos do art. 187 do CC. ${ }^{8}$

\subsection{A ação regressiva do Estado contra o agente público}

Como pessoa jurídica, o Estado, entidade real, embora abstrata, não possui vontade nem ação - que se entende como manifestação psicológica e vida anímica próprias - porque só os seres físicos possuem. É o agente público que atua em seu nome, que exprime a manifestação estatal munido de uma qualidade que só possui porque o Estado lhes emprestou sua força jurídica e os habilitou para assim agirem. (MELLO, 1984, p. 61).

Segundo Celso Antonio Bandeira de Mello, a relação entre a vontade e a ação do Estado e de seus agentes é uma relação de imputação direta dos atos dos agentes ao Estado, isto é, por ato próprio. Logo, aquilo que o agente queira ou faça entende-se que foi o Estado quem quis ou fez. Não se bipartem Estado e agente público, ao contrário, são considerados uma unidade, sendo o Estado o próprio agente que descumpriu a conduta devida dada a relação mantida com seu agente baseada na teoria do orgânica. (MELLO, 2000, p. 15).

Contudo, o legislador definiu critérios de responsabilização diversos para o Estado e para seu agente público. Isso porque, no próprio art. $37, \S 6^{\circ}$ da $\mathrm{CF}$, há duas regras jurídicas: da responsabilidade objetiva do Estado e da responsabilidade subjetiva do agente público, pois, além da norma primária sancionadora que impõe ao Estado o dever de ressarcir os danos resultantes da conduta do agente público e da norma secundária que permite ao lesado requerer ao Poder Judiciário que, por meio de atos coativos, imponha a execução forçada do patrimônio público para o cumprimento do dever jurídico, o referido artigo estabelece uma segunda norma primária sancionadora com a correspondente norma secundária, as quais regulam a relação jurídica do Estado com o agente público causador do dano, já que foi estabelecida a possibilidade de ajuizamento de ação de regresso em face do agente público que atuou com dolo ou culpa, assim: "assegurado o direito de regresso contra o responsável no caso de dolo ou culpa".

BRASIL. Superior Tribunal de Justiça. AgRg no Agravo em Recurso Especial n. 426.631/RS. Relator Ministro Humberto Martins. Brasília. Julgamento em 6/2/2014. 
A ação de regresso tem natureza civil e destina-se a recompor o erário que se desequilibrou em razão do valor pago ao particular devido ao ato lesivo. O sujeito ativo é o Estado em seus quatro níveis, ou suas entidades, e o sujeito passivo é o agente público que agiu com dolo ou culpa, cuja prova deverá ser efetuada nos autos, tendo como pressuposto o trânsito em julgado da condenação da entidade pública em ressarcir o particular lesado.

Ressalte-se que, dado o enunciado acima descrito, o contribuinte (ou responsável) que sofreu o dano pode propor a ação de ressarcimento de danos contra o agente público que praticou a conduta, que responderá com o próprio patrimônio, e não exclusivamente em face do Estado. Em tal caso, aplica-se a teoria subjetiva devido à previsão constitucional expressa que impõe que o agente público tenha atuado com dolo ou culpa. Por isso, no que se refere à responsabilidade do agente público, a vítima do dano disputaria a lide só no campo da responsabilidade subjetiva. (MACHADO, 2011, p. 482).

Além da responsabilização do agente público que atua em nome do Fisco em âmbito civil, é possível responsabilizá-lo penalmente pela exigência de um tributo indevido ou, quando devido, se, na cobrança, houver empregado meio vexatório ou gravoso não autorizado pela lei, conforme dispõe o art. $316, \S 1^{\circ}$ do CP ao regular o crime de excesso de exação, cuja pena é de 3 a 8 anos de reclusão e multa.

\subsection{Condutas omissivas do agente público}

Os atos omissivos (negativos) constituem um non facere relevante para o Direito por atingir um bem juridicamente tutelado. Ensejará a responsabilidade do Estado se houver a violação do dever do agente público de intervir em certa situação para evitar a ocorrência do dano. Aplica-se a teoria subjetiva que exige a demonstração da culpa lato sensu, pois sua essência está em não se ter agido de certo modo quando a ação era necessária, já que, se o Estado não agiu, não pode logicamente ser considerado o autor do dano, sendo responsabilizado apenas se for obrigado a impedi-lo. Logo, requer a efetiva potencialidade do agir associada ao dever jurídico de fazê-lo.

A dificuldade refere-se à possibilidade de agir do agente público, razão pela qual a responsabilidade do Estado por condutas omissivas apenas pode ser analisada diante do caso concreto. Requer-se que a conduta seja exigível da Administração Pública e possível. Constitui uma forma de aplicação do princípio da razoabilidade.

Para Celso Antonio Bandeira de Mello e Maria Silvia Zanella Di Pietro, aplica-se a presunção de culpa às condutas omissivas, pois o elemento culpa lato sensu considera-se embutido na ideia de omissão. Por conseguinte, cabe ao Estado demonstrar que: i) agiu com diligência, ii) utilizou os meios adequados e disponíveis, e iii) se não agiu naquela situação, é porque sua atuação estaria acima do que seria razoável exigir. Nesse 
sentido, não é papel do lesado provar que a omissão foi culposa. (DI PIETRO, 2011, p. 716).

Logo, a responsabilidade estatal por ato omissivo é sempre por conduta ilícita, sendo necessária a demonstração da negligência, da imprudência ou da imperícia, ou ainda do deliberado propósito de violar a norma na hipótese em que era obrigatório para o Estado atuar e fazê-lo segundo certo padrão de eficiência capaz de obstar o evento lesivo.

Por exemplo, o não exercício da autotutela pelo agente público que deixa de anular um ato ilegítimo pode constituir uma omissão qualificada pela violação das normas de diligência (negligência e imprudência) ou por dolo que caracterizam o ilícito capaz de tornar o dano passível de ressarcimento. Ocorre com a não anulação administrativa por órgãos de julgamento em contencioso administrativo tributário do lançamento tributário ou de auto de infração desconformes com posicionamentos consolidados pelo STF ou STJ, favoráveis ao contribuinte, em Controle Concentrado de Constitucionalidade, Recursos Extraordinários com repercussão geral reconhecida, Súmulas Vinculantes e Recursos Especiais repetitivos, obedecendo à sistemática dos arts. 543-B e 543-C do CPC/73, que correspondem ao art. 1.036 a 1.041 do NCPC, sempre que os atos tributários acima mencionados (lançamento tributário propriamente dito e auto de infração para aplicação de penalidade) versem sobre a mesma questão jurídica decidida, mas foram praticados em sentido oposto ao da decisão invocada como paradigma acima nominadas.

Em outros termos, em Processo Administrativo Tributário, por meio do qual a questão poderia ser resolvida evitando maiores dissabores ao contribuinte ou com um prejuízo passível de ser tolerado em razão da possibilidade de suspender automaticamente a exigibilidade do crédito fiscal, conforme o inciso III do art. 151 do CTN - apesar de a impugnação apresentada pelo alegado devedor, o agente público não intervém tempestivamente para anular o lançamento referente a tributo incontestavelmente indevido, fazendo com que o contribuinte suporte os danos decorrentes do ajuizamento da ação judicial bem como os ônus e a demora do julgamento do processo, o que poderia ser evitado, pois era sabido que os atos seriam fatalmente anulados em âmbito judicial.

Em tais casos, além do dever de corrigir atos ilegais que decorre do princípio de legalidade, em razão dos princípios de eficiência, de boa-fé e do dever de colaboração, os quais, em conjunto com os demais princípios administrativos e tributários, compõem a noção de boa administração, é possível afirmar a existência do dever jurídico do Fisco de evitar que o contribuinte suporte os danos inerentes ao ajuizamento da ação anulatória fiscal (manejada para obter a tutela jurisdicional de controle da atividade fiscal requerendo a anulação do ato tributário), tais como: a necessidade de efetuar o depósito do valor do montante integral em dinheiro, conforme dispõe o inciso II do art. 151 do CTN, o caput 
do art. 38 da Lei n. 6.830/90 e a Súmula n. 112 do STJ, para suspender a exigibilidade do crédito fiscal a fim de impedir o aforamento e as consequências da execução fiscal.

Essas considerações são relevantes, pois justificam a própria existência do processo administrativo, por meio do qual há possibilidade do lançamento tributário ou auto de infração que apresente vício capaz de torná-lo ilegítimo ser anulado com menor dano ao contribuinte, sobretudo em razão da suspensão automática do crédito tributário e da permissão para impugnar o ato sem a necessidade de contratar advogado.

Sublinhe-se que a omissão na anulação do ato pelo agente vinculado à Administração Tributária será a causa do dano apenas nos casos em que o lançamento ou auto de infração, isto é, a atividade primária do agente público for realizada sem qualquer negligência - considerando as declarações prestadas pelo próprio contribuinte e sua situação no momento da lavratura do ato -, mas, posteriormente, ocorrer alguma alteração por ele informada, a qual é ignorada pelo Fisco que deixa de anular o ato praticado.

É possível imaginar a seguinte situação: dada a complexidade das normas jurídicas tributárias e a inexistência de posicionamento consolidado a respeito da interpretação adequada sobre a aplicação da norma ao caso concreto - como a incidência de imposto sobre serviços (ISS) em relação à locação de bens móveis em certo período não podem ser considerados ilegítimos os atos de cobrança e imposição de multa lavrados pelos agentes públicos àqueles que não recolheram o imposto ao exercer a referida atividade.

No entanto, após a manifestação do STF por meio da edição da Súmula Vinculante n. 31 que declara expressamente ser descabido o ISS em relação à locação de bens móveis, compete à Administração Tributária anular os atos tributários de cobrança do tributo e imposição de multa, podendo inclusive atuar ex officio. Se deixar de anular a cobrança, haverá omissão ilícita do Fisco, cujos resultados danosos serão passíveis de ressarcimento.

Esclarece-se, contudo, que, na maior parte das vezes, o nexo causal dá-se entre o dano e a atividade primária do agente público, ou seja, com a própria emissão do ato de lançamento ou imposição de multa ilegítimo, e não com a sucessiva negativa da anulação do ato tributário em autotutela por parte do Fisco.

\subsection{Dano}

No Direito, o termo "dano" não possui a mesma extensão do senso comum, que corresponde à noção naturalística, pois não se refere a qualquer prejuízo. Noutras palavras: na vida cotidiana, inúmeras situações podem ser experimentadas pelos indivíduos como danosas, porém nem todas se amoldam ao conceito jurídico de dano, já que a noção naturalística não coincide com a jurídica. 
Segundo a noção jurídica, o sentido de dano é mais restrito, referindo-se exclusivamente ao prejuízo relevante e tutelável pelo Direito, isto é, ao dano qualificado pela antijuridicidade, intitulado "dano injusto" pelo legislador italiano por reconhecer que nem todo prejuízo em sentido econômico pode ser considerado um prejuízo em sentido jurídico. (FLUMIGNAN, 2009, p. 40).

Há outra diferença entre as duas concepções de dano que corresponde à necessidade de que o sujeito que sofreu o prejuízo seja diverso daquele que praticou a conduta produzindo-o. Para a noção naturalística, não importa se o dano é causado pelo próprio sujeito que sofreu o prejuízo ou por terceiro, porém, a noção jurídica não concebe o dano causado a si mesmo, de modo que o dano resultante da conduta praticada pelo próprio sujeito está fora da ideia da responsabilidade civil.

Isso é relevante em matéria fiscal, pois, conforme analisado anteriormente, na maior parte das vezes, é o próprio contribuinte que verifica a ocorrência do fato gerador, calcula o montante devido e efetua o pagamento do tributo, cabendo à Administração Tributária conferir a apuração efetuada e o pagamento realizado. Trata-se das hipóteses de "autolançamento", que somente autoriza o ressarcimento dos danos que resultarem da conduta do agente público de revisão e emissão de lançamento de ofício em caráter suplementar.

Portanto, a ideia básica do conceito jurídico de dano relaciona-se à violação causada por um sujeito a bem ou interesse jurídico de terceiro e à consequência dessa lesão, que se refletirá no objeto do ressarcimento.

Apesar de ser um fenômeno unitário, o dano possui dois aspectos que se referem aos dois momentos de sua ocorrência: i) dano-evento, que corresponde à lesão de direitos subjetivos ou interesses jurídicos relevantes; e, ii) dano-consequência, que equivale ao prejuízo econômico efetivamente suportado, que servirá como referência para o ressarcimento.

Logo, a partir de tais considerações, entende-se que a ação causadora do dano, ou conduta (lícita ou ilícita), produz um evento danoso, que será considerado ilícito se revelar a lesão de direito subjetivo ou de interesse jurídico relevante, denominado "dano evento", além do prejuízo econômico que normalmente a ele se associa como consequência material, intitulado "dano consequência", sendo esse o sentido jurídico de dano.

Assim sendo, não basta que a suposta vítima se considere lesada, é necessário que o dano seja reputado relevante pela sociedade, isto é, que traduza a lesão de um direito subjetivo ou de interesse juridicamente protegido, pois é o que determina a contrariedade ao Direito, além do dano econômico, ou prejuízo efetivamente sofrido.

Em vista do exposto, a primeira conclusão a que se chega é a seguinte: a conduta lícita ou ilícita que não produz dano algum não enseja responsabilidade do 
Estado. Isso se aplica inclusive em âmbito tributário, de forma que a ação de ressarcimento de danos proposta pelo contribuinte contra o Estado requer a existência de um prejuízo concreto resultante da relação tributária. Isso porque não é certo que da violação das normas jurídicas na prática da conduta decorra necessariamente dano: há ilegalidade, ilegitimidade. $\mathrm{O}$ dano é uma realidade autônoma que deverá ser verificada em cada caso específico. Se com a mera anulação do ato praticado pelo Fisco repõe-se a ordem jurídica, não há que se falar em responsabilidade do Estado.

Conforme mencionado ao examinar as características da conduta ilícita, o ato ilegítimo não constitui fonte de responsabilidade do Estado, já que resulta da violação da lei, da incompetência ou do excesso de poder, os quais por si só não ensejam a responsabilidade. É necessário que o ato contrário ao Direito produza resultado danoso para que seja gerador de responsabilidade civil; do contrário, pode ser sanado apenas com a sua anulação.

Por exemplo: se o agente público constatar a presença de um vício formal no lançamento tributário que seja capaz de invalidar a constituição do crédito fiscal - tal como o erro de fato na indicação da área cadastral do imóvel inferior à sua área real - o ato pode ser revisto de ofício e anulado em autotutela antes mesmo de ensejar danos ao contribuinte. Apesar de vigorar o princípio da imutabilidade do lançamento tributário, em certas situações estabelecidas no art. 149 do CTN, admite-se a sua alteração ex officio.

É também possível imaginar o caso em que o contribuinte recebe a notificação do ato de lançamento efetuado de ofício pela Administração Tributária nas situações previstas em lei e efetua sua impugnação pela via administrativa devido à suspensão automática do crédito fiscal. Ao final do processo administrativo, reconhecese a existência de vício no lançamento que é anulado sem consequências prejudiciais ao contribuinte, que sequer foi representado por profissional habilitado.

Logo, o raciocínio desenvolvido neste estudo parte do pressuposto de que o dano é consequência de uma conduta com a qual não se confunde, apesar dela resultar. Em vista disso, entende-se que um aspecto da responsabilidade do Estado se refere ao caráter lícito ou ilícito da conduta praticada; e, o outro, à juridicidade ou antijuridicidade do dano. Ambos os aspectos são relevantes, porém, considera-se o último como fator determinante da responsabilidade do Estado por dano tributário.

Noutros termos: tanto a conduta ilícita quanto a lícita podem produzir dano passível de ressarcimento desde que seja possível qualificá-lo como antijurídico (ilícito), sendo a antijuridicidade (ilicitude) identificada na lesão dum direito subjetivo ou de interesse jurídico relevante para o Direito, não podendo ser justificado com base em nenhuma regra da ordem jurídica.

Conforme já afirmado, há situações em que o legislador impõe o dever de ressarcimento apenas na hipótese em que o dano decorre da conduta ilícita, destacando-se 
a culpa do agente que se conduziu de determinada forma (em sentido amplo). Nesses casos, aplica-se a teoria da responsabilidade subjetiva, pois o objeto de interesse corresponde à valoração da conduta praticada pelo sujeito causador do dano e não ao prejuízo sofrido pelo lesado. Isso se verifica nas relações entre particulares, nas condutas estatais omissivas e na ação regressiva do Estado em face do agente público.

Contudo, há situações em que é irrelevante a valoração da conduta, já que o foco da responsabilidade recai sobre a conjuntura da vítima do dano, devido ao interesse do legislador de recompor o cenário ao status quo ante, elevando-se o caráter compensatório da sanção. Sucede na aplicação da teoria da responsabilidade objetiva, na qual existe dever de ressarcimento mesmo quando não houver a violação do dever de cuidado, no que se inclui a responsabilidade por condutas lícitas. Nesse sentido, na responsabilidade objetiva, a conduta causadora do dano poderá ser lícita, mas o resultado danoso deverá ser necessariamente ilícito, pois a ilicitude é um componente que deve estar presente: na conduta e no dano, ou apenas no dano.

De acordo com Fernando Dias Menezes de Almeida: "se o Direito prevê, para o Estado, responsabilidade objetiva, o Estado responderá tanto nas situações em que tiver havido culpa, como naquelas em que não tiver havido". Afirma: "o Direito Constitucional fixa para o Estado apenas um sistema de responsabilidade extracontratual que absorve tanto as situações decorrentes dos ditos atos lícitos, como as decorrentes dos atos ilícitos de agentes públicos”. Apenas não é necessário, para a incidência da responsabilidade, demonstrar a culpa. (ALMEIDA, 2008, p. 17).

Em síntese, o sistema brasileiro de responsabilidade do Estado leva à cogitação de que há dever de ressarcir também quando o dano resulta da prática de atos lícitos, contudo, nesse caso, não basta a relação objetiva de causalidade entre a conduta e o dano, havendo que estar envolvido algum elemento de ilicitude, o que pode ser constatado no próprio dano. Conforme Almeida: "a ilicitude que necessariamente deve estar presente na relação de responsabilidade do Estado não precisa estar na ação ou omissão estatal, mas sim no resultado". (ALMEIDA, 2008, p. 17).

3.2.1. Responsabilidade do Estado pelo resultado danoso ilícito decorrente da conduta lícita

Parte-se do pressuposto de que o resultado danoso ilícito como consequência de conduta lícita é uma situação excepcional, já que, até por uma questão lógica, se o legislador disciplinou na própria lei o modus operandi da Administração Pública delineando as condutas que devem ser praticadas, obviamente, estabeleceu um padrão de conduta destinado a evitar a ocorrência de prejuízos para viabilizar a construção de um relacionamento profícuo entre o Estado e o sujeito passivo da relação tributária. 
Contudo, ainda que o Estado adote todas as diligências necessárias para evitar a causação de danos, obedecendo a todos os parâmetros estabelecidos pela ordem jurídica, em determinados casos, não é possível evitar sua ocorrência em relação a um ou outro particular. Daí não ser admissível deixar alguma pessoa ou grupo sofrer uma oneração maior imposta pelo Estado para a realização do bem comum somente com base na justificativa de que todas as precauções possíveis foram adotadas.

A conduta lícita requer a conformidade do ato com o Direito e a ausência de culpa lato sensu; e, o resultado danoso igualmente lícito pressupõe o transcurso in albis do prazo para pagamento do tributo ou da multa efetivamente devidos, ou seja, o descumprimento do dever jurídico pelo contribuinte (ou responsável) de pagar o tributo cujo fato gerador realmente ocorreu, ou a penalidade, nos termos do art. 113 do CTN, o que impõe a ativação dos instrumentos legais voltados à satisfação forçada do débito, isto é, para a cobrança do tributo nos exatos termos da lei. Em síntese: o tributo é devido e há inadimplemento do sujeito passivo da obrigação tributária justificando a ação causadora e o dano. Contudo, se o tributo não é devido, o dano suportado pelo contribuinte (ou responsável) é considerado ilícito e, portanto, passível de ressarcimento.

Parece estranha a ideia de que, ao exigir o pagamento de tributo indevido - que regra geral caracteriza a conduta como ilícita - o agente público pode estar agindo licitamente, sendo somente o dano ilícito. No entanto, essa afirmação é possível ao considerar que os atos administrativos são dotados de "presunção de legitimidade" e que, além disso, em alguns casos, não existe culpa lato sensu do agente público na prática do ato.

Trata-se de presunção iuris tantum posta pelo Direito de que todo o processo de realização do ato se deu nos moldes das normas jurídicas que o regulam até que se prove e se constitua o contrário, visto que se trabalha com o controle de validade dos atos a posteriori. Isto posto, a presunção de legitimidade dos atos administrativos somada à ausência de culpa lato sensu confere o caráter lícito à conduta do agente público até o reconhecimento e a declaração da ilegitimidade.

Partindo do pressuposto, nos termos do art. 186 do CC, de que a conduta ilícita é formada pela contrariedade ao Direito (antijuridicidade), que constitui seu aspecto objetivo, e pela culpa lato sensu, que identifica seu aspecto subjetivo, será lícita a conduta praticada conforme o Direito e, obviamente, sem o descumprimento do dever de diligência característico das condutas culposas, vale dizer, sem a culpa lato sensu.

Logo, é possível que o agente público, mesmo adotando todas as cautelas necessárias, pratique um ato que, apesar de visivelmente ilegítimo, é considerado válido e eficaz em virtude da presunção de legitimidade que permite ao Fisco submeter o contribuinte às consequências gravosas da cobrança do crédito tributário, ainda que o ato seja declarado ilegítimo tempos depois. Nesse sentido, devido à presunção de legitimidade 
e à ausência de culpa lato sensu na atuação do agente público, a conduta é considerada lícita.

Retoma-se o exemplo já mencionado, no qual: diante da inexistência de interpretação consolidada do STF ou do STJ (em repercussão geral e recursos repetitivos que seja favorável ao contribuinte) sobre a aplicação da lei tributária para um caso específico ou na presença de conflito jurisprudencial sobre o tema (que é inerente à complexidade da legislação tributária), não pode ser reputada ilícita a conduta do agente público de realizar o lançamento tributário ou o auto de infração por entender que sobre certo serviço incide ISS em vez de ICMS. Isso porque, dada a imprecisão sobre a interpretação adequada para a aplicação de determinada norma jurídica ao caso concreto, não há culpa lato sensu do agente público na prática dos referidos atos tributários, o que exclui o caráter ilícito da conduta.

Além disso, em razão da presunção de legitimidade, que torna o ato válido e eficaz, não é possível falar em contrariedade ao Direito, até que se prove o contrário, de modo que o Fisco poderá buscar a satisfação do crédito fiscal pela inscrição do débito em dívida ativa (CDA) e o ajuizamento da execução fiscal, praticando atos dirigidos à constrição do patrimônio do devedor, tais como: penhoras e bloqueios de bens, inscrição do nome no CADIN e indeferimento de certidões negativas de débito.

Tudo isso é lícito ao Fisco em razão da presunção de legitimidade que recai sobre o ato, da ausência de interpretação administrativa ou jurisprudencial consolidada, bem como da existência de conflito jurisprudencial que descaracterizam a culpa lato sensu na conduta do agente público, e da situação de inadimplemento do sujeito passivo da relação tributária baseada nas circunstâncias como foram apresentadas à Administração Pública - ainda que posteriormente seja reconhecida a ilegitimidade da cobrança em razão de grave vício que leva à nulidade do ato, como a ausência de motivo que constitui pressuposto elementar do ato de cobrança por não ter sido praticado o fato gerador do ISS.

Além da possibilidade de defender-se em processo de execução fiscal por embargos à execução ou exceção de pré-executividade (em alguns casos), admite-se o ajuizamento da ação anulatória do débito, que requer, para a suspensão da exigibilidade do crédito tributário, a realização do depósito do valor do seu montante integral, podendo gerar danos ao contribuinte devido à indisponibilidade dos recursos, por exemplo.

Diante desse contexto: se, ao final do processo judicial, o lançamento tributário ou o auto de infração forem declarados nulos, reconhecendo-se que o serviço prestado pelo contribuinte não condiz com a hipótese de incidência do ISS, mas sim do ICMS, verificar-se-á que o ato, originalmente, era ilegítimo, ou seja, contrário ao Direito, embora a conduta pudesse ser considerada lícita pelas razões anteriormente expostas.

Parte-se da premissa de que o sacrifício dos direitos do contribuinte apenas é possível se for efetuado dentro do limite da ação legítima da Administração Tributária. No 
caso analisado, a perseguição do crédito fiscal apoiou-se na presunção de legitimidade do lançamento, que é um atributo do ato administrativo que recai sobre a conduta, tornando-a legítima (até prova em contrário), mas que não é suficiente para justificar o dano suportado pelo contribuinte, isto é, para caracterizá-lo como lícito, pois só o descumprimento de um dever jurídico realmente existente pode justificar a aplicação das sanções estabelecidas em lei, não uma mera presunção. Noutros termos: só o efetivo dever jurídico de pagar tributo justifica a privação de direitos do contribuinte, caso contrário, existe verdadeira lesão do bem jurídico que qualifica o dano como ilícito.

Na medida em que o crédito tributário é desconstituído pelo Poder Judiciário em consequência do reconhecimento de vício que anulou o lançamento, é possível afirmar a inexistência de causa suficiente e relevante que justifique o peso de suportar os danos resultantes da prática de atos que incidem de maneira tão autoritária e gravosa na esfera jurídica de seu destinatário, implicando a privação do direito de gozar e de utilizar do bem.

Dito de outra forma, a aplicação do consequente da norma primária sancionadora que impõe deveres ao contribuinte como a sanção pelo descumprimento da obrigação tributária (penalidades pecuniárias ou multas fiscais), além da norma secundária com atos de execução forçada (execução fiscal) só pode ocorrer legitimamente se houver o descumprimento do disposto na norma primária dispositiva, isto é: se a dívida em relação à qual o contribuinte figura como inadimplente realmente existir. Caso contrário, se verifica o dever do Estado de ressarcir o dano causado dado o seu caráter ilícito.

Desse modo, existe o dever jurídico do Estado de ressarcir o dano suportado pelo contribuinte (ou responsável) recompondo sua situação ao status quo ante se for aplicada a sanção estabelecida no consequente da norma primária sancionadora sem a ocorrência de seu pressuposto, isto é, sem o descumprimento do dever jurídico prescrito na norma primária dispositiva.

$\mathrm{Na}$ inexistência do dever de pagar tributo, o dano é ilícito, isto é, lesivo a direitos subjetivos, pois a ablação do patrimônio e a execução forçada de bens, que resulta da relativização de direitos fundamentais imposta pela lei, é permitida tão somente se houver o dever jurídico de pagar o tributo e o respectivo descumprimento, caso contrário há nítida violação de direitos. Logo, a ausência da dívida caracteriza a ilicitude do dano, ensejando a responsabilidade do Estado apesar da conduta do agente público ser considerada lícita.

Se não há descumprimento do dever de pagar o tributo ou a multa fiscal por parte do contribuinte, o dano sofrido com a execução forçada de bens, a contratação de profissionais habilitados, a inscrição no CADIN, o indeferimento de certidões negativas de débitos, revela a lesão de direitos subjetivos como a propriedade, a liberdade e a livre iniciativa, e não a sua legítima limitação. 
A partir de agora, será analisada a segunda situação em que a hipótese "conduta lícita com resultado danoso ilícito" pode ser aplicada, contudo, o tributo é efetivamente devido pelo contribuinte, tendo transcorrido in albis o prazo para pagamento. Ou seja, a conduta é legítima e não há culpa lato sensu do agente público, pois os atos praticados estão amparados pela lei, sendo o próprio contribuinte quem motivou a ativação dos instrumentos destinados à satisfação do crédito tributário, já que figura efetivamente como inadimplente.

Em tal caso, a ilicitude resulta da lesão à proporcionalidade pelos efeitos excessivamente gravosos resultantes das medidas adotadas pelo agente público, previstas em lei, destinadas à satisfação do crédito tributário. Danos que, apesar de resultarem de conduta praticada sob a escora de uma regra jurídica, poderiam e deveriam ser evitados, o que caracteriza a lesão de direitos subjetivos do devedor à propriedade, à liberdade e à livre iniciativa; e, ao direito à eficiência (boa administração) no exercício das atividades públicas, que é um dever da Administração Pública de caráter vinculante. (FREITAS, 2009, p. 42).

Se há uma disciplina de preservação da esfera jurídica do contribuinte em âmbito administrativo e tributário que prescreve a realização do fenômeno tributário em acordo com os princípios jurídicos que disciplinam os limites do Poder de Tributar, tais como legalidade, capacidade contributiva, progressividade, além daqueles que regulam a ação administrativa como eficiência (boa administração), boa-fé, razoabilidade, proporcionalidade etc., é porque há uma preocupação com a possibilidade de que a potencialidade lesiva inerente a tais atos cause lesão à direitos e interesses do contribuinte, sacrificando-os além do limite aceitável pelo próprio ordenamento jurídico. ${ }^{9}$

No Direito italiano, conforme ensina Guido Falzone, boa administração significa desenvolver a atividade administrativa "do modo mais congruente, mais oportuno e mais adequado aos fins a serem alcançados, graças à escolha dos meios e da ocasião de utilizá-los, concebíveis como os mais idôneos para tanto”. (FALZONE, 1953, p. 64).

Segundo a tradução de Celso Antonio Bandeira de Mello: “a norma só quer a solução excelente", que certamente não é a satisfação do crédito tributário com a ruína do devedor, mas sim com o menor sacrifício. Desse modo, se houver meios que sejam menos gravosos ao devedor e, ao mesmo tempo, eficazes para a satisfação do crédito da Administração Pública, é essa a solução excelente, em acordo com a boa administração. (MELLO, 2000, p. 126).

O princípio da eficiência (boa administração) deve ser aplicado pelo Fisco em todos os níveis de atuação. Remete à ideia de proporcionalidade das técnicas definidas

BRASIL. Superior Tribunal de Justiça. REsp n. 1.337.790 - PR. Relator Ministro Herman Benjamin. j. 12.6.2013, Dje 7/10/2013. 
e do exercício das competências, isto é, adequação dos meios aos fins e proibição do excesso, contrapondo-se ao descaso, à negligência e à omissão.

Considera-se transgressão à proporcionalidade e à eficiência, a prática de atos como penhoras sobre maquinário da empresa (necessário ao desempenho de atividades empresariais) e do imóvel em que estão instaladas as atividades industriais, se houver outros meios eficazes para a garantia do juízo que não impeçam o exercício da atividade econômica do devedor, possibilitando-lhe auferir recursos para pagar a própria dívida tributária.

Frise-se que o poder de tributar, cujas limitações se encontram no próprio texto constitucional, não pode chegar à desmedida do poder de destruir, inclusive no que se refere à execução fiscal, arruinando o devedor para satisfazer os interesses do credor quando existiam soluções mais moderadas e igualmente eficazes para ambas as partes.

Nas situações acima referidas, o dano suportado pelo devedor é ilícito, sobretudo em razão da lesão do direito à eficiência (boa administração) nas atividades administrativas, visto que a Fazenda Pública poderia e deveria ter evitado o prejuízo, mas não o fez, produzindo a lesão ao direito à propriedade, à liberdade e, em certos casos, à livre iniciativa, que se manifesta por meio de danos emergentes e lucros cessantes.

Para que o dano seja ilícito em razão da falta de eficiência na realização de atos voltados à satisfação do crédito tributário, é necessário que existam outros meios também eficazes para garantir a dívida e que isso seja de conhecimento da Fazenda Pública, de maneira que a escolha de um determinado bem, embora legítima, pois amparada por uma norma jurídica, torna-se desproporcional em razão dos efeitos gravosos produzidos, os quais poderiam ser evitados com a adoção de uma solução mais moderada.

Não significa sacrificar o direito de crédito do Fisco, mas atender à sua exigência de adimplemento da dívida com o menor sacrifício do devedor, sempre que for possível. Não se pode esquecer de que o interesse público é a síntese de todos os interesses juridicamente relevantes, de modo que o interesse privado é a dimensão do interesse público de ver respeitada a propriedade, o livre exercício das atividades econômicas, a dignidade da pessoa humana, a capacidade contributiva etc.

Outrossim, ao selecionar os bens penhoráveis, a Fazenda Pública não pode pensar só nos interesses do credor, mas deve analisar com cuidado o grau de incisão da decisão sobre a esfera jurídica do contribuinte, respeitando também os interesses do último, ou seja, dando o justo peso aos interesses de ambas as partes. No conceito de boa administração, inclui-se a obrigação de sacrificar o mínimo possível para preservar o máximo os direitos do administrado, de forma que o Estado deve ser responsabilizado por toda e qualquer quebra nuclear de proporcionalidade. De acordo com o referido princípio: "as escolhas administrativas serão legítimas - e somente se - forem sistematicamente 
eficazes, sustentáveis, motivadas, proporcionais, transparentes, imparciais e ativadoras da participação social, da moralidade e da plena responsabilidade".

\subsection{Nexo de causalidade}

Segundo Edmir Netto de Araújo, nexo de causa e efeito significa que a relação necessária entre o fato gerador do evento, o dano e o sujeito a quem se pretende responsabilizar somente se verificará se a causa for idônea para tanto. Logo, não é qualquer causa que deflagrará a responsabilidade: se a causa é inidônea a relação de causa e efeito nem chega a se formar ou logo se rompe com as excludentes de responsabilidade. (ARAÚJO, 2010, p. 791).

Regra geral, na teoria objetiva, é suficiente a presença do nexo causal, eliminando a perquirição de qualquer elemento psíquico e volitivo do agente causador do dano, pois basta a identificação do vínculo etiológico que se constata na atividade do Estado como causa e no dano sofrido pelo particular como consequência. (CAHALI, 2012, p. 30).

Importante registrar que o Direito brasileiro não se filiou à teoria do risco integral que obriga sempre o Estado a ressarcir o dano causado e nem à teoria da culpa administrativa que leva em conta o binômio falta do serviço e culpa da Administração Pública. Adotou a teoria do risco administrativo, em que surge a obrigação de ressarcimento do dano causado pelos agentes públicos pelo fato do só ato lesivo e injusto causado à vítima. Basta a lesão, sem o concurso do lesado, posto que se exige somente o fato do serviço.

Apenas haverá responsabilidade do Estado quando o autor da ação de ressarcimento de dano provar que a conduta do agente público é causa eficiente do dano, já que, necessariamente, o prejuízo de que se queixa deve ser consequência da ação ou omissão administrativa, por exemplo: em decorrência da inscrição indevida do nome no CADIN, fornecedores deixaram de entregar matéria prima, impossibilitando o cumprimento de contratos que ensejou não só a perda de clientes, pois denegriu a imagem da empresa, mas também a aplicação de elevada multa contratual; dado o indeferimento da certidão negativa de débitos fiscais ou da certidão positiva com efeitos negativos, o sujeito foi impedido de participar de procedimento licitatório, entre outras situações possíveis.

Conclusões

1. O Direito brasileiro permite ao intérprete desse sistema normativo, por meio da interpretação dos enunciados prescritivos estabelecidos na Constituição Federal de 1988 (art. 37, caput e $\S 6^{\circ}$, e art. 150), no Código Tributário Nacional (art. 97) e no Código Civil (art. 927), imputar a responsabilidade ao Estado pelos danos sofridos 
pelo sujeito passivo da relação tributária (contribuinte ou responsável) em razão dos atos praticados pelo agente público no exercício da função fiscal, que compreende a fiscalização, a constituição, a inscrição e a cobrança do crédito tributário.

2. A responsabilidade do Estado por dano tributário decorre da presença de princípios que regulam o modus operandi da Administração Tributária limitando o poder de tributar e da previsão expressa contida no $\S 6^{\circ}$ do art. 37 e no inciso XXXV do art. $5^{\circ}$ da CF que prescrevem à Administração Pública o dever de ressarcir os danos causados por seus agentes e a possibilidade do lesado de provocar o Poder Judiciário para, mediante a coatividade estatal, impor seu cumprimento. Caracteriza-se como a contrapartida da legalidade.

3. A conjugação dos princípios que delineiam a prática de atos pela Administração Tributária (art. 150 da CF) com os princípios que regulam o modus operandi da ação administrativa (art. 37, caput, da CF) e a previsão da responsabilidade estatal (art. 37, $\S 6^{\circ}$ da CF) possibilita concluir logicamente que, no Direito brasileiro, está presente a norma primária dispositiva: "se é o poder-dever do Estado de tributar o cidadão, então deve ser a proibição de causar-lhe danos"; e, consequentemente, da norma primária sancionadora: "se o Estado causar dano ao cidadão no exercício do poder-dever de tributar, então deve ser a obrigação do Estado de ressarcir o dano causado"; além da norma secundária que determina a ação coativa do Estado-Juiz impondo a execução forçada de bens do infrator, ou seja, do Estado.

4. Aplica-se à responsabilidade do Estado por dano tributário, regra geral, a teoria objetiva, que se baseia no risco administrativo. No entanto, a teoria subjetiva é empregada em duas situações, nas quais é necessário demonstrar a culpa lato sensu: i) se o dano resultar de condutas omissivas do agente público, como deixar de anular atos ilegais para restaurar a legalidade violada por meio da autotutela; e, ii) em ação regressiva movida pelo Estado em face do agente público. Nesses dois casos, só a conduta ilícita enseja o dever de ressarcir.

5. Para deflagrar a responsabilidade do Estado, impondo-lhe o dever jurídico de ressarcir os danos causados por seus agentes públicos, requer-se a presença dos elementos essenciais, ou seja: i) conduta (lícita ou ilícita); ii) dano ilícito (lesão de direitos subjetivos); e, iii) nexo de causalidade entre os dois primeiros.

6. A conduta (lícita ou ilícita) gera um evento danoso ilícito se for identificado no dano a violação de direitos subjetivos do administrado, denominado "dano evento", além do prejuízo econômico que normalmente se associa na forma de uma consequência material, intitulado "dano consequência". Esse é o sentido jurídico do termo dano, que constitui objeto da responsabilidade do Estado e que se aplica inclusive em âmbito tributário. 
7.Ailicitude do dano corresponde à contrariedade ao Direito(antijuridicidade) que se revela na lesão de direitos subjetivos, como: propriedade, liberdade, personalidade e exercício de profissão, dispostos no art. $5^{\circ}$ da CF; livre iniciativa econômica, segundo o art. 170 da CF; e, o leque de direitos que resultam da relação normal entre a Administração Pública e o cidadão num Estado de Direito, por exemplo: legalidade, igualdade, eficiência, proporcionalidade, razoabilidade, boa-fé, colaboração, visto que é direito subjetivo do administrado a atuação da Administração Pública em conformidade com os princípios do ordenamento jurídico brasileiro.

8. Para imputar a responsabilidade ao Estado, o elemento "ilícito" deve estar presente tanto na conduta quando no resultado danoso, sendo ambos ilícitos, ou somente no resultado danoso; caso contrário, não há dever de ressarcimento do dano causado pelo agente público. Logo, apenas haverá responsabilidade do Estado nas hipóteses: conduta ilícita com resultado danoso ilícito e conduta lícita com resultado danoso ilícito.

9. Há dano ilícito como consequência da conduta lícita também na situação em que o tributo é efetivamente devido pelo contribuinte tendo transcorrido in albis o prazo para pagamento, porém existe lesão ao direito de eficiência (boa administração) que se vislumbra na violação da proporcionalidade dado os efeitos excessivamente gravosos em consequência de atos praticados pela Fazenda Pública, ainda que sob a escora duma regra jurídica, os quais poderiam ter sido evitados.

10. Para que exista dever jurídico do Estado de ressarcir os danos resultantes de condutas lícitas, além do dano revelar a violação de uma situação jurídica legítima suscetível de configurar um direito subjetivo, deverá ser: i) certo e não eventual, podendo ser atual ou futuro; e, ii) anormal.

11. O dano será certo se efetivamente existir, mesmo que os efeitos não ocorram na atualidade, mas no futuro; e, anormal, se extrapolar o dever de tolerância mínima, ao qual todos estão sujeitos em razão do convívio social, por ser proporcionalmente maior do que aquilo que deve ser normalmente suportado por qualquer membro da sociedade em virtude do exercício das atividades públicas.

São Paulo, 22 de maio de 2017.

\section{Referências.}

ALESSI, Renato. L'illecito e la responsabilità civile degli enti pubblici. 2. ed. riveduta e aggiornata. Milano: Giuffrè, 1972.

ALMEIDA, Fernando Dias Menezes de. Responsabilidade extracontratual do Estado por atos lícitos: ensaio em homenagem a Guido Soares. In: CASELLA, Paulo Borba et al (Org.). Direito 
internacional, humanismo e globalidade: Guido Fernando Silva Soares - Amicorum Discipulorum Liber. São Paulo: Atlas, 2008.

ALMEIDA, Fernando Dias Menezes de; CARVALHO FILHO, José dos Santos. Controle da administração pública e responsabilidade do Estado. In: DI PIETRO, Maria Sylvia Zanella (Coord.). Tratado de direito administrativo. 1. ed. São Paulo: Editora Revista dos Tribunais, 2014. v. 7.

AMARAL, Francisco. Os atos ilícitos. In: FRANCIULLI NETTO, Domingos; MENDES, Gilmar Ferreira; MARTINS FILHO, Ives Gandra da Silva (Coord.). O novo código civil. Estudos em homenagem ao professor Miguel Reale. 2. ed. São Paulo: LTr, 2006.

ARAÚJO, Edmir Netto de. Curso de direito administrativo. 5. ed. rev. e atual. São Paulo: Saraiva, 2010 .

AZEVEDO, Álvaro Villaça. Conceito de ato ilícito e o abuso de direito. In: RODRIGUES JUNIOR, Otavio Luiz; MAMEDE, Gladston; ROCHA, Maria Vital da. (Coord.). Responsabilidade civil contemporânea. Em homenagem a Sílvio de Salvo Venosa. São Paulo: Atlas, 2011.

BESSONE, Mario. I criteri di imputazione della responsabilità civile. In: BESSONE, Mario. Casi e questioni di diritto privato. 8. ed. Milano: Giuffrè, 2000. v. 9/1: Atto illecito e responsabilità civile.

CAHALI, Yussef Said. Responsabilidade civil do Estado. 4. ed. rev., atual. e ampl. São Paulo: Revista dos Tribunais, 2012.

CARVALHO, Paulo de Barros. Curso de direito tributário. 23. ed. São Paulo: Saraiva, 2011.

CAVALIERI FILHO, Sergio. Programa de responsabilidade civil. 11. ed. São Paulo: Atlas, 2014.

COSTA, Regina Helena. Curso de direito tributário. Constituição e Código Tributário Nacional. 2. ed. São Paulo: Saraiva, 2012.

CRETELLA JÚNIOR, José. Tratado de direito administrativo. Rio de Janeiro: Forense, 1970. v. 8.

DANTAS, Francisco Clementino de San Tiago. Programa de direito civil: parte geral. 4. tir., Rio de Janeiro: Ed. Rio, 1983.

DI PIETRO, Maria Sylvia Zanella. Responsabilidade civil do Estado. In: RODRIGUES JUNIOR, Otavio Luiz; MAMEDE, Gladston; ROCHA, Maria Vital da. (Coord.). Responsabilidade civil contemporânea. Em homenagem a Sílvio de Salvo Venosa. São Paulo: Atlas, 2011.

FALZONE, Guido. Il dovere di buona amministrazione. Milano: Giuffrè, 1953.

FLUMIGNAN, Silvano José Gomes. Dano-evento e dano-prejuizo. 2009. Dissertação (Mestrado) - Faculdade de Direito, Universidade de São Paulo, São Paulo, 2009.

FREITAS, Juarez. Discricionariedade Administrativa e o direito fundamental à boa administração pública. 2. ed. São Paulo: Malheiros Editores, 2009.

GONÇALVES, Carlos Roberto. Direito civil brasileiro. Responsabilidade civil. São Paulo: Saraiva, 2009. v. 4. 
JURINSKI, James John. Tax reform. California: ABC-CLIO, 2000.

MACHADO, Hugo de Brito. Responsabilidade no direito tributário. In: RODRIGUES JUNIOR, Otavio Luiz; MAMEDE, Gladston; ROCHA, Maria Vital da. (Coord.). Responsabilidade civil contemporânea. Em homenagem a Sílvio de Salvo Venosa. São Paulo: Atlas, 2011.

MARINS, James. Direito processual tributário brasileiro: administrativo e judicial. 8. ed. São Paulo: Dialética, 2015.

MARQUES, José Frederico. Tratado de direito penal. 2. ed. São Paulo: Saraiva, 1965. v. 2.

MELLO, Celso Antônio Bandeira de. Apontamentos sobre os agentes e órgão públicos: regime jurídico dos funcionários públicos. São Paulo: Revista dos Tribunais, 1984. p. 61.

MELlo, Celso Antônio Bandeira de. Curso de direito administrativo. 12. ed., 2. tiragem, rev., ampliada e atualizada até a Emenda Constitucional 24, de 9.12.1999. São Paulo: Malheiros, 2000.

SANTI, Eurico Marcos Diniz de; SCAPIN, Andreia Cristina. PGFN e Receita Federal dão passo para segurança jurídica. Consultor Jurídico, São Paulo, p. 1, fev. 2014. Disponível em: <https://www. conjur.com.br/2014-fev-27/pgfn-receita-federal-dao-passo-seguranca-juridica-contribuintes>.

SCHOUERI, Luis Eduardo. Direito tributário. 4. ed. São Paulo: Saraiva, 2014.

STANZIONE, Pasquale. Manuale di diritto privato. 3. ed. Torino: G.Giappichelli, 2013.

STOCO, Rui. Tratado de responsabilidade civil: doutrina e jurisprudência. 8. ed. rev., atualizada e ampliada com comentários ao Código Civil. São Paulo: Revista dos Tribunais, 2011. 
